\title{
Exploring Causal Relationships for Geoheritage Interpretation - Variable Effects of Cenozoic Volcanism in Central European Sedimentary Tablelands
}

\author{
Piotr Migoń ${ }^{1}$. Edyta Pijet-Migoń ${ }^{2}$
}

Received: 15 September 2021 / Accepted: 10 November 2021 / Published online: 28 December 2021

(c) The Author(s) 2021

\begin{abstract}
Modern conceptual approach to geointerpretation and geoeducation emphasizes the holistic understanding of the environment and attends to linkages between various abiotic, biotic, and cultural components. In this paper, we highlight multiple relationships between Cenozoic volcanism and host sedimentary rocks, mainly sandstones of Cretaceous age, which can be explored in the context of geotourism and geoeducation in several Central European geoparks (Bohemian Paradise UNESCO Global Geopark, Land of Extinct Volcanoes Aspiring Geopark, Ralsko National Geopark) and their surroundings. These include the effects of magmatism on sandstones, with further consequences for landform development at different spatial scales, the origin of mineral resources, underpinning of biological diversity, and specific land use contrasts. Existing interpretation provisions are reviewed, and a three-tiered framework to show these different linkages is proposed. It is argued that different, but complementary themes can be addressed at the landscape, landform, and individual outcrop (geosite) level.
\end{abstract}

Keywords Geotourism $\cdot$ Geoparks $\cdot$ Interpretation $\cdot$ Rock-controlled landforms $\cdot$ Ironstones

\section{Introduction}

Holistic approach to the environment is at the core of geopark idea (Zouros and Valiakos 2010; Ólafsdóttir and Dowling 2014; Pásková and Zelenka 2018; Pásková et al. 2021). Likewise, geotourism, even though focused on geoheritage, builds upon general landscape appreciation and aims to raise awareness of mutual causal connections between geological past, present-day environments, and human activities (Newsome and Dowling 2005; Hose 2008, 2010; Dowling and Newsome 2018; Gordon 2018a, b). The presence of outstanding geoheritage as a prerequisite to create a geopark, and the role of geodiversity and georesources as factors underpinning both biodiversity values and cultural heritage of an area have been emphasized since the

Piotr Migoń

piotr.migon@uwr.edu.pl

1 Institute of Geography and Regional Development, University of Wrocław, pl. Uniwersytecki 1, 50-137 Wroclaw, Poland

2 WSB University in Wrocław, Fabryczna 29-31, 53-609 Wroclaw, Poland beginning of the initiative. Nowadays, the ABC concept (abiotic-biotic-cultural) is increasingly promoted in geoparks (Gray 2011; Dowling 2013; Ólafsdóttir and Tverijonaite 2018; Pásková et al. 2021), but it seems that more efforts are spent to show linkages between these three components than to explore relationships between different components of geoheritage and geodiversity themselves. In fact, geological history and geomorphological evolution are not a series of unrelated events, separated by vast intervals of geological timescale, but are logical sequences of processes that can be deciphered from the rock record and the physical landscape. These sequences provide a background to public-oriented storytelling and are ideally presented by means of thematic trails, where one theme opens the way to introduce another one (Ren et al. 2013, Migoń and Pijet-Migoń 2017a, Pica et al. 2018, Henriques and dos Reis 2021). If the rock and landscape records are visually appealing and thematically intriguing, opportunities to engage visitors increase. The latter comment particularly applies to volcanic geoheritage, which is often associated with spectacular landforms (volcanic cones, lava plateaus) and geological structures (columnar jointing, thick layered pyroclastic deposits), but in the interpretation realm, it can be also related to the contemporary volcanism and its consequences for both 
natural landscapes and the society (Erfurt-Cooper 2010, 2014; Abratis et al. 2015; Zangmo Tefogum et al. 2016; Lima et al. 2018; Scarlett and Riede 2019; Becerra-Ramírez et al. 2020; Dóniz-Páez et al. 2020; Németh et al. 2021). However, whereas a multitude of examples how past volcanism is presented to and interpreted for the public can be provided, its wider context and relationships with other aspects of geoheritage and landscape history, both natural and cultural, seem less explored, at least in Central Europe, where the evidence of Neogene volcanic activity is abundant (e.g., Harangi 2014; Szepesi et al. 2017; Megerle 2020). Megerle (2020) provided an up-to-date review of volcanic geoheritage in geoparks in Germany and concluded that in many cases, it is insufficiently promoted to the public, being part of 'invisible geoheritage' as in the Swabian Alb. Consequently, relationships between landforms and materials of volcanic origin and other natural and cultural values are seldom highlighted, although exceptions occur and these are focused on the use of stone and groundwater resources, linkages with wine culture, and potential to preserve fossil record in ancient maar depressions (Megerle 2020).

In this paper, we intend to show multiple linkages between two building blocks of geological history of a sedimentary tableland, located in the territories of Czechia, Poland, and Germany. These are (a) the sedimentary record of the Permian and the Mesozoic, particularly the
Cretaceous, which includes an extensive platform cover, largely preserved until now despite Cenozoic denudation, and (b) the record of subsequent volcanic and subvolcanic activity that occurred within these sedimentary basins. Younger magmas, mainly of basaltic composition, protruded the older sedimentary cover, and hence, rocks of different origin and age occur side by side (Adamovič et al. 2006; Janoška 2013; Pijet-Migoń and Migoń 2019). We argue that the coexistence of these two rock complexes offers ample opportunities to develop geointerpretation and geoeducation, not yet fully explored, and the main aim of this study is to show the evidence to support this assertion. The case will be primarily illustrated by examples from three geoparks located not far away from one another - the Bohemian Paradise UNESCO Global Geopark (Czechia), the Land of Extinct Volcanoes Aspiring Geopark (Poland) and the Ralsko National Geopark (Czechia), but selected localities from their vicinities will be also considered (Fig. 1). The focus on geoparks reflects one of the main goals of these territorial organizations, which is to develop awareness and better understanding of geoheritage through appropriate interpretation and geoeducation. Our approach to the issue is twofold. On one hand, we will review the existing resources available in the study areas to see if and how these relationships are included into geotourist products available now. On the

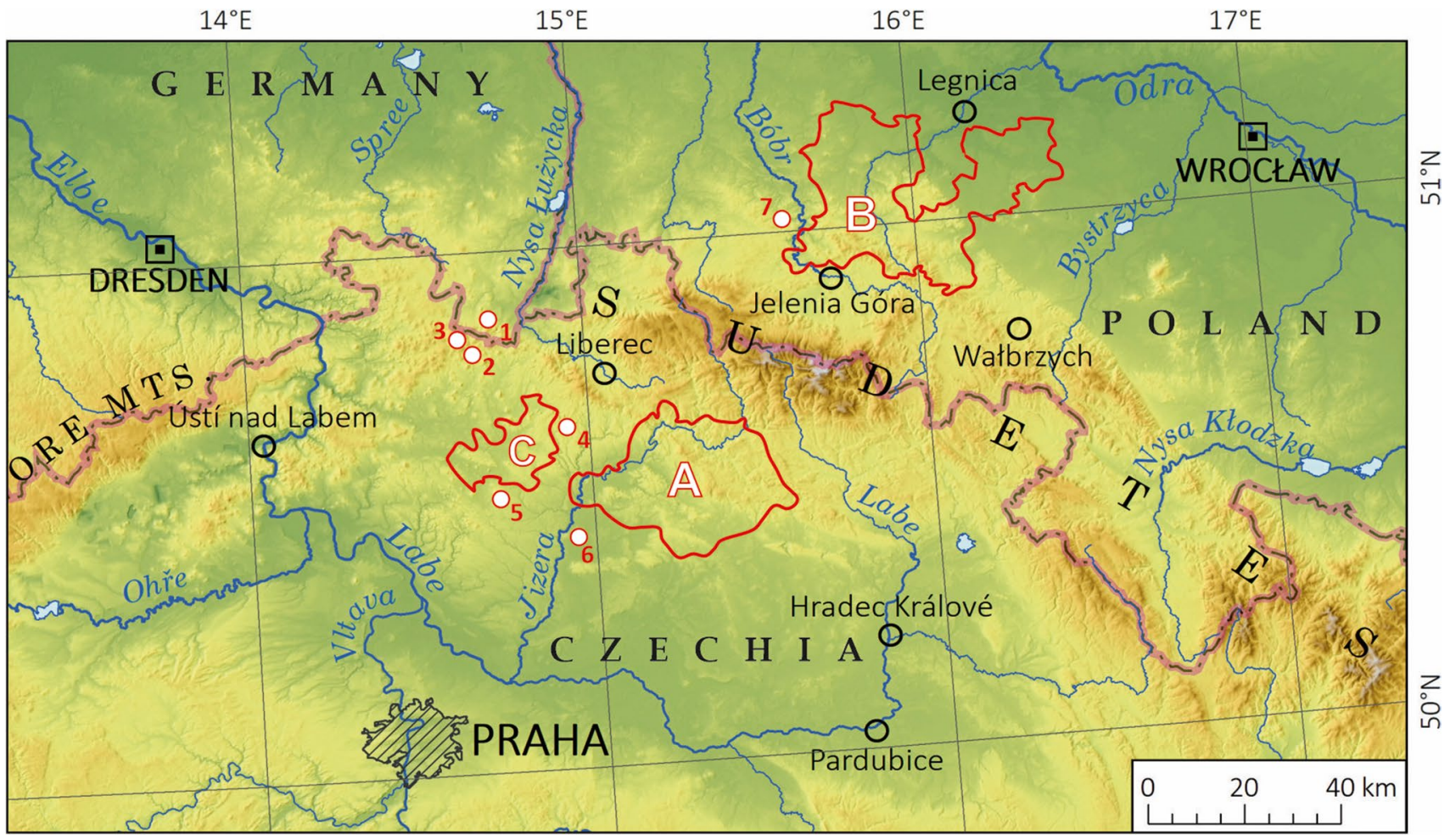

Fig. 1 Location map. Geoparks: A — Bohemian Paradise, B — Land of Extinct Volcanoes, C — Ralsko. Other localities: 1 - Zittauer Gebirge, 2 - Dutý kámen, 3 - Milštejn, 4 - Čertova zed', 5 - Bezděz, 6 - Baba, 7 - Łupki 
other one, we will offer suggestions where and how existing geointerpretation can be expanded to better emphasize mutual linkages.

\section{Data Sources and Methods}

This study is based on three main types of sources. First, an extensive literature survey was carried out to obtain (a) proper geological and geomorphological background and context and (b) relevant information about geosites, the development of geotourism, and geoeducation in the study areas. All three areas have a long history of research in geoscience, and the publication database is abundant, whereas the field of geotourism is relatively new and less represented. Therefore, as a complementary and possibly more up-to-date source, official websites of the three geoparks were used (see website resources). It was assumed that they provide the most accurate information about geoeducational activities undertaken in each area. Moreover, we intended to check how (or if) volcanic/sedimentary interactions are presented to the general public that might like to consult these sources. Third, field work was an essential part of the study. All three geoparks and other relevant sites were visited several times to see the current state of geotourist provisions, the integrity of actual and potential geosites, and to evaluate possible challenges associated with geointerpretation and education. A combination of literature survey and field work allowed us to identify several themes that integrate volcanic heritage with other types of (geo)heritage, whereas further conceptual work resulted in the proposal of a tiered structure of interpretation as the one capable to adequately address scale issues. Figure 2 summarizes the approach adopted for the purpose of this study.

\section{Study Areas}

\section{UNESCO Global Geopark Bohemian Paradise}

The Bohemian Paradise UNESCO Global Geopark (UGG) in northern Czechia (Fig. 3) covers an area of $833 \mathrm{~km}^{2}$,

PRIMARY RESOURCES

SECONDARY RESOURCES
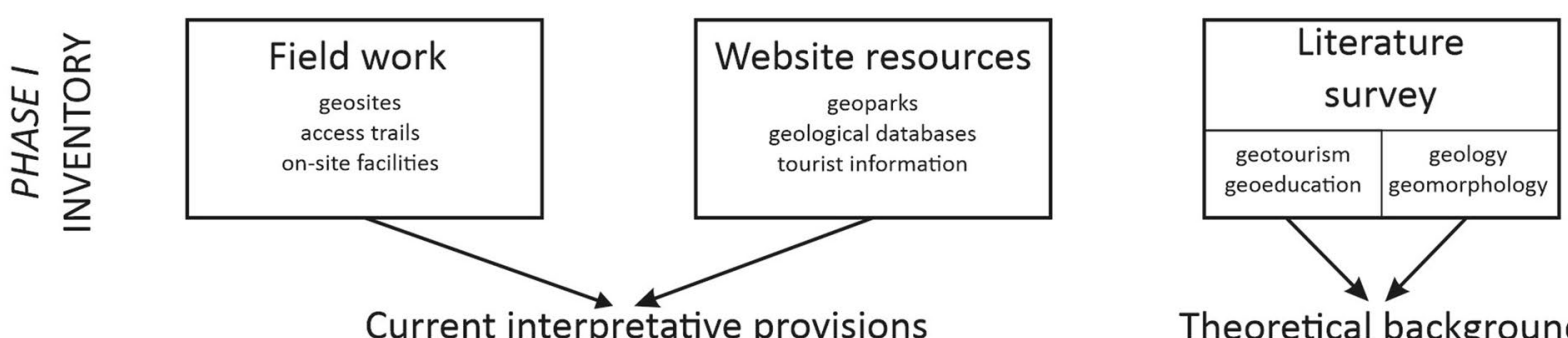

Theoretical background

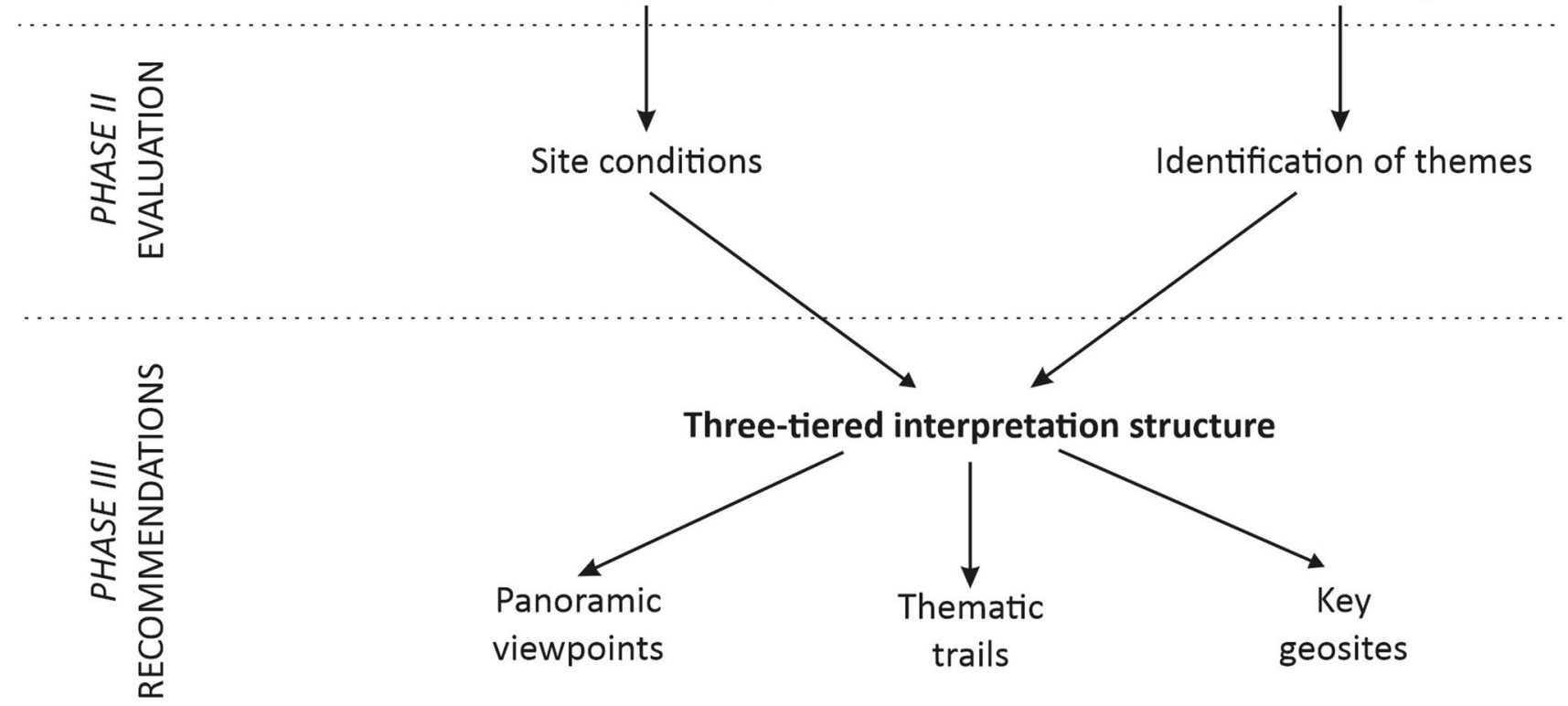

Fig. 2 Flowchart to illustrate the structure of research adopted for this study 


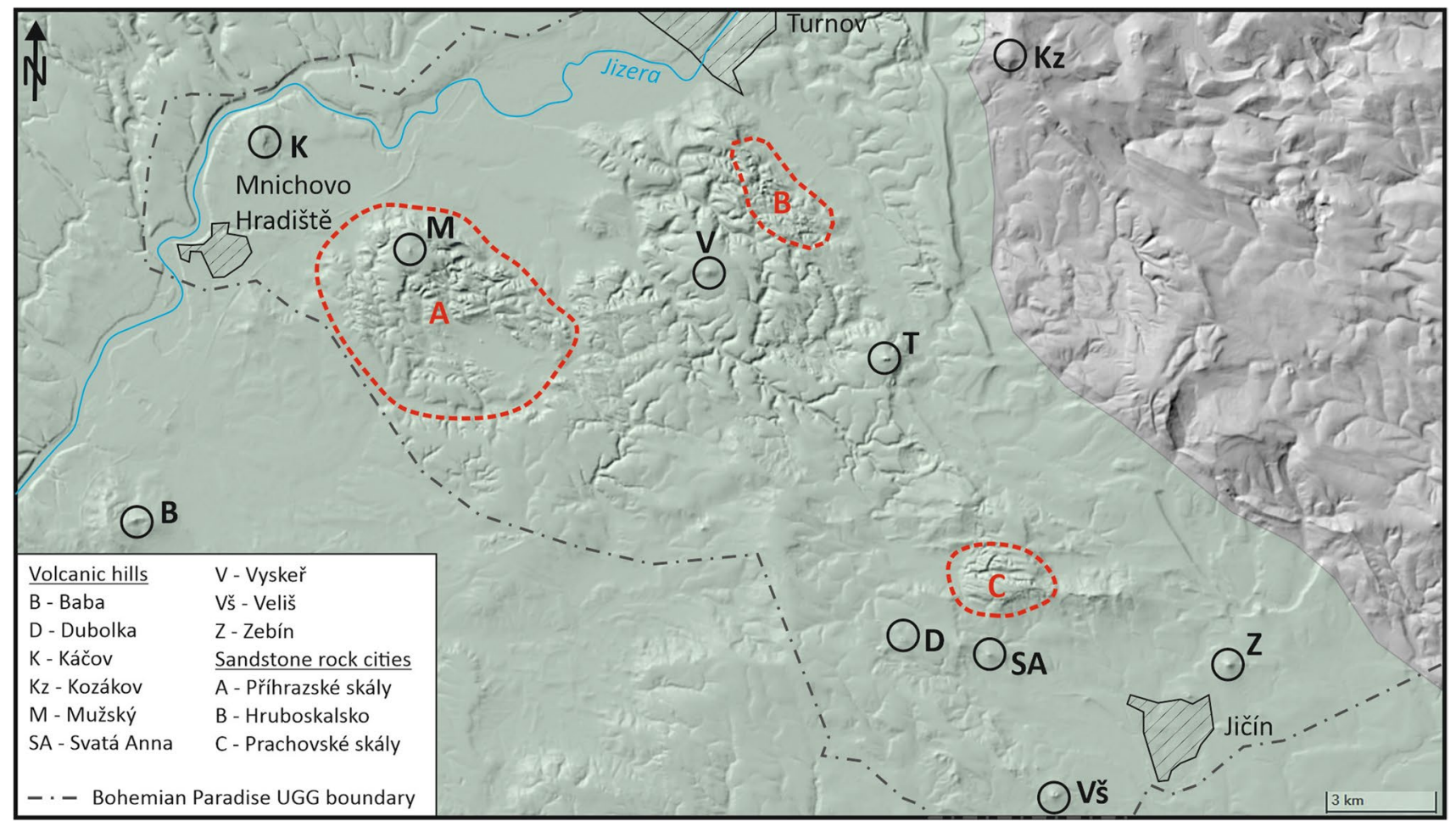

Fig. 3 Relief of the south-western part of the Bohemian Paradise UNESCO Global Geopark, with location of sites and areas mentioned in text. The relief model best highlights the difference between subdued lowlands and dissected plateaus on Cretaceous strata, and iso-

which is highly diverse geologically and includes spectacular geomorphological landscapes such as rock cities, cliffed sandstone escarpments, and residual hills of various shapes built of volcanic rocks of various ages (Adamovič et al. 2006; Mertlik and Adamovič 2016). The Bohemian Paradise UGG integrates three different geological units: early Palaeozoic basement in the north, dominated by phyllites, schists, and diabase; a Permo-Carboniferous sedimentary basin in the east, with numerous occurrences of Permian and Cenozoic eruptive rocks; and a part of the Bohemian Cretaceous Basin in the south-west, with thick sequences of shallow marine deposits, mainly sandstones and mudstones, and a few outcrops of volcanic rocks of Cenozoic age (Uličný 2001; Adamovič et al. 2006; Rapprich et al. 2007). This geological complexity is mirrored by geomorphological diversity of the geopark area, which includes the northern part, with river valleys deeply incised into a rolling upland on basement rocks, hilly topography on Permian rocks in the east (maximum altitude is present here - Mt. Kozákov, 744 $\mathrm{m})$, cuestas and hogback ridges in the centre-west, and the dismembered sandstone tableland in the south-west. The latter is locally considerably dissected to form intricate patterns of cliff-lined valleys and rock cities (Hruboskalsko, Prachovské skály) (Vítek 1980; Škvor 1982; Adamovič et al. 2006). lated hills built of volcanic rocks (in circles). Green colour shows the extent of Cretaceous strata, undifferentiated. Source of relief map: https://ags.cuzk.cz/geoprohlizec; the extent of Cretaceous cover after Mertlik and Adamovič (2016)

Younger volcanic rocks support conical hills, broader domelike elevations, and basaltic pinnacles such as the regional landmark of Trosky (Petronis et al. 2015), as well as less conspicuous lava flows (Cajz et al. 2009) (Fig. 4).

The name of Bohemian Paradise (Český ráj in Czech) is unofficial and was likely introduced in the nineteenth century by visitors to the spa resort of Lázně Sedmihorky, located at the foot of a sandstone rock city of Hruboskalsko (Kubaliková 2016; Drápela et al. 2021). Among the most popular places for visitors were the ruins of Trosky castle, where one of the medieval castle towers was converted into a viewing tower. In the 1930s, following the initiative of the Club of Czech Tourists (KČT), a c. 120-km-long hiking trail named as the 'Golden Route of the Bohemian Paradise' was waymarked. It connects the most attractive localities in the region, from both natural and cultural perspective, and remains popular until today.

An increasing popularity of the Bohemian Paradise, especially its sandstone rock cities, and resultant human impact prompted introduction of legal conservation measures. The first nature reserve was established in the Prachovské skály rock city in 1933, whereas in 1955 , the most visited part of the area, including Hruboskalsko, Trosky 

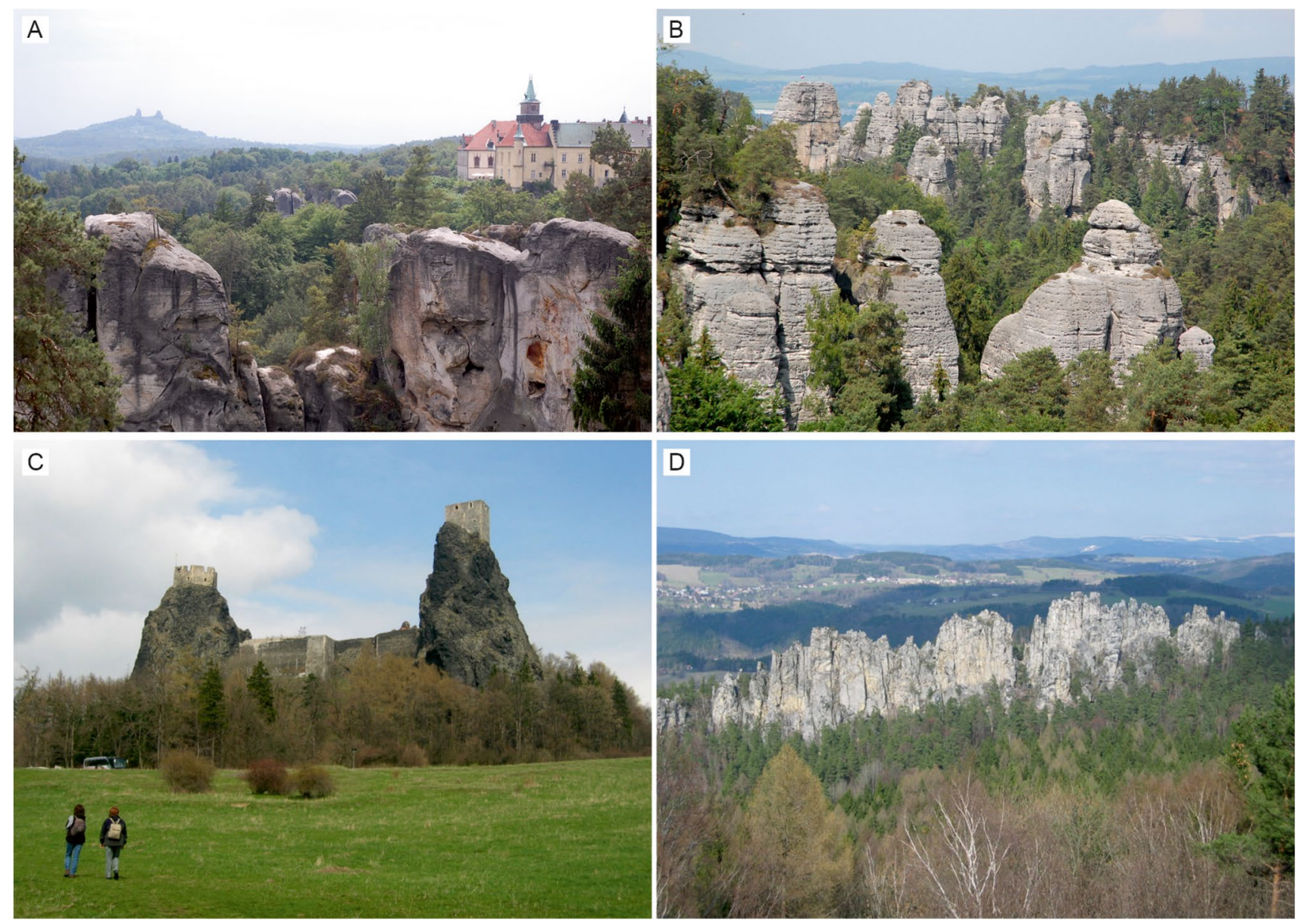

Fig. 4 Geoheritage in the Bohemian Paradise UNESCO Global Geopark. A Sandstone rock formations in the front and volcanic hill of Trosky on the skyline. The chateau of Hrubá Skála is seen on the right; B sandstone rock city of Hruboskalsko; $\mathbf{C}$ twin volcanic plugs

castle and Přihrazy plateau, was declared by a ministerial decree as the Protected Landscape Area (CHKO), covering $92 \mathrm{~km}^{2}$ and becoming the first protected area of this kind in the former Czechoslovakia. In 2002, the protected area was enlarged to $181.5 \mathrm{~km}^{2}$. Simultaneously, nomination for UNESCO World Heritage was considered, but eventually the area was nominated for the status of European Geopark and joined the network in 2005 (Adamovič et al. 2006). Until now, it is the only Czech geopark in the network of UNESCO Global Geoparks. The geopark covers a much larger area than the Protected Landscape Area, initially more than $700 \mathrm{~km}^{2}$, later expanded to $833 \mathrm{~km}^{2}$ (Drápela et al. 2021). However, despite various efforts to popularize different parts of the geopark, whose geoheritage also includes important sites of Palaeozoic volcanism (Migoń and Pijet-Migoń 2020), tourist visitations remain very unevenly distributed in space and strongly concentrated in sandstone rock cities. of Trosky, with ruins of a medieval castle; D hogback ridge of Suché skály is built of hardened Cretaceous sandstone, upturned to vertical in the vicinity of the Lusatian Fault

\section{Aspiring UNESCO Global Geopark Land of Extinct Volcanoes}

The aspiring UGG Land of Extinct Volcanoes is located in the north-western part of the Sudetes range, in southwestern Poland (Figs. 1, 5). Geologically, it covers partly the basement unit of the Kaczawskie Mountains zone and, partly, the North-Sudetic Synclinorium, which is a mildly deformed late Variscan and post-Variscan sedimentary basin. In the latter, thick successions of Permian and Upper Cretaceous rocks occur, more than $1 \mathrm{~km}$ in total. They are dominated by continental clastic rocks in the Lower Permian; marine sediments, including limestones and dolomites in the Upper Permian; and quartz sandstones and mudstones in the Upper Cretaceous. However, the core values of the geopark are related to an extensive record of past volcanic activity, spanning the interval from the Early Palaeozoic to the Neogene (Pijet-Migoń and Migoń 2019). Within it, the legacy of Cenozoic volcanism is most evident, with numerous 
Fig. 5 Relief of the western part of Land of Extinct Volcanoes Geopark area, with location of sites and areas mentioned in text. Green colour shows the extent of Cretaceous strata; brown stands for pre-Cretaceous sedimentary rocks; selected hills built of volcanic rocks in circles. Source of relief map: https://www.geoportal.gov. $\mathrm{pl}$; the extent of sedimentary formations after Adam (2004)

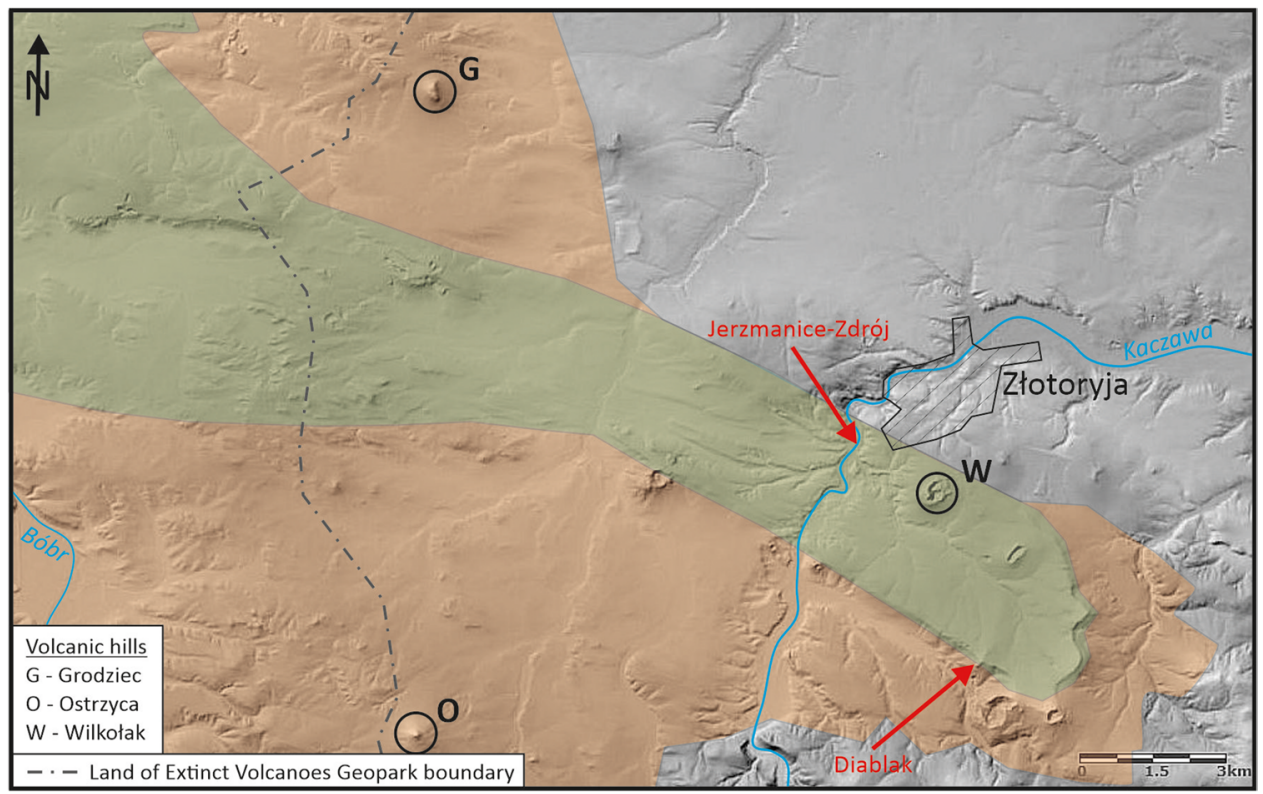

cones and domes protruding through the sedimentary basin (Fig. 6). The highest one, Mt. Ostrzyca (501 m), is a regular basaltic cone of $150 \mathrm{~m}$ of relative relief and a regional landmark.

In Poland, geoparks are not a form of legal protection or territorial organization. Nevertheless, in 2017, an agreement was signed by the local municipalities to work towards eventual inclusion of the region into the UNESCO Global Geopark network and the name 'Land of Extinct Volcanoes Geopark' is increasingly used (Pijet-Migoń and Migoń 2019; Stomski et al. 2019). The area of the aspiring geopark covers $1263 \mathrm{~km}^{2}$ and includes 14 municipalities, both urban and rural. Population amounts to 105,000 , with the mean population density of 83 people per $1 \mathrm{~km}^{2}$. Demographic problems are common, related to ageing of local population and migrations to bigger towns. The name of the geopark copies the brand name of the region, introduced by the Local Action Group Kaczawskie Partnership in the early twenty-first century to enhance visibility of the area and to promote nature-based tourism. Prior to that, the region was essentially neglected by tourists, although well-known and appreciated by geoscientists for its rich geological and geomorphological heritage. Indeed, promotional strategy of the last 15 years or so is clearly focused on geoheritage and geotourism (Rogowski 2016; Pijet-Migoń and Migoń 2019), although the ABC concept is evidently followed. A milestone in the development of geoeducation was the opening of an educational centre in the village of Dobków in 2015, focused on volcanic history. It can be visited individually or on a guided tour, but the main target groups are school parties and various kinds of workshops run by professional educators are the main offer (Pijet-Migoń and Migoń 2019, Słomski et al. 2019).

\section{Ralsko National Geopark}

Ralsko National Geopark was established in northern Czechia, a few tens of kilometres west of the Bohemian Paradise UGG (Fig. 7). It covers c. $300 \mathrm{~km}^{2}$ of a sedimentary tableland, rather subdued for most of its extent, but with higher, dissected plateau remnants and solitary residual hills in the north and south-west, whereas the eastern part of the
Fig. 6 Volcanic and sedimentary geoheritage of the Land of Extinct Volcanoes Geopark. A Basaltic cone of Mt. Ostrzyca; $\mathbf{B}$ an old sandstone quarry in the village of Jerzmanice-Zdrój
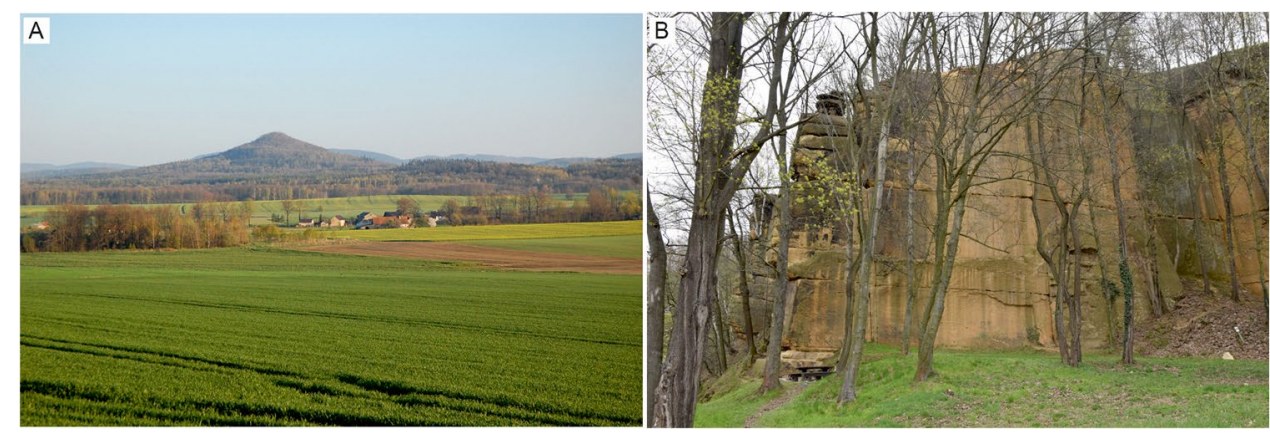
Fig. 7 Relief of the Ralsko Geopark area and the surroundings, with location of sites and areas mentioned in text. The relief model best highlights the difference between subdued lowlands and dissected plateaus on Cretaceous strata, and isolated hills built of volcanic rocks or hardened sandstone. Green colour shows the extent of Cretaceous strata, undifferentiated. 'NPP' stands for National Nature Monument. Source of relief map: https://ags.cuzk. cz/geoprohlizec; the extent of Cretaceous cover after https:// mapy.geology.cz/geocr50/

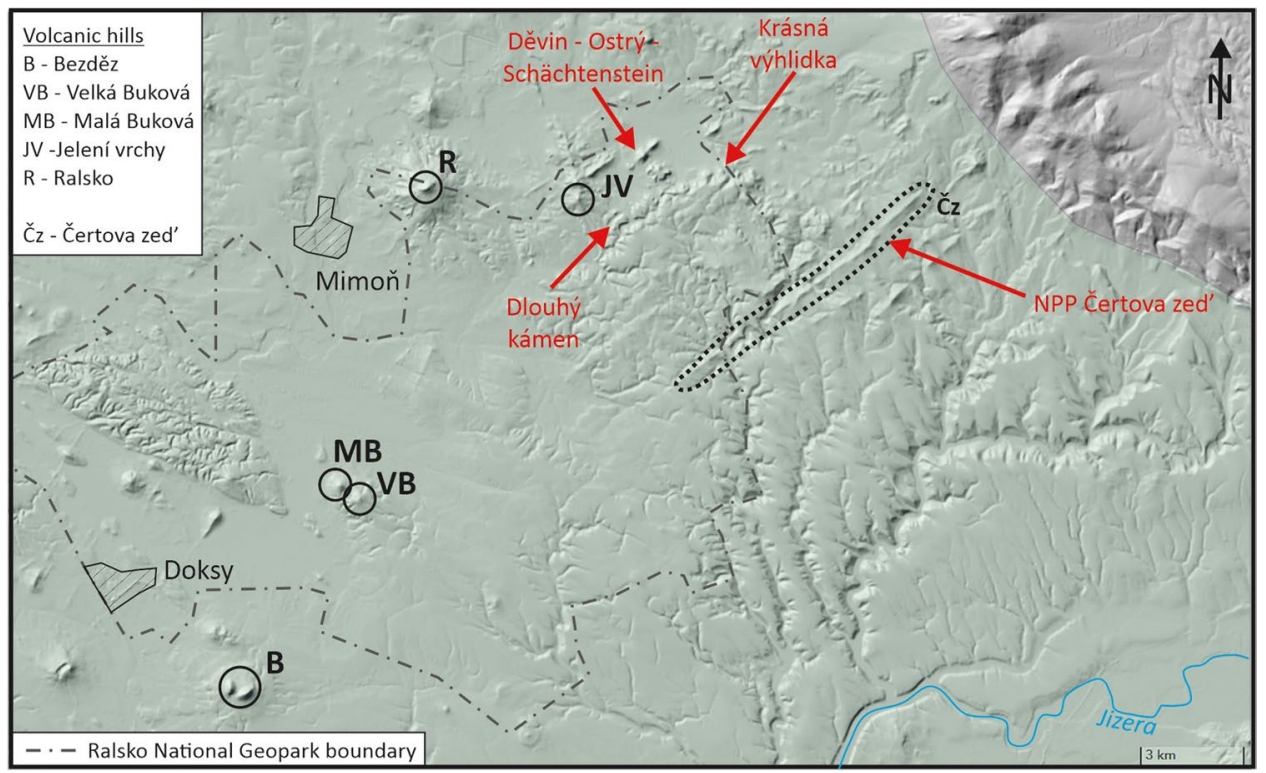

tableland is markedly incised by fluvial valleys. Altitudes are mostly $350-450 \mathrm{~m}$ a.s.1. The age of bedrock is Late Cretaceous and the dominant lithologies are sandstones and siltstones of marine origin (Skoček and Valečka 1983; Uličný et al. 2009). In the late Cretaceous, subvolcanic processes were taking place, producing numerous polzenite dykes of mainly SW-NE strike, whereas the main period of neo-volcanic activity occurred in the Oligocene-Miocene (Ulrych et al. 2011). The evidence is provided by numerous exposed volcanic conduits (necks), some reaching nearly $400 \mathrm{~m}$ of relative height (Mt. Ralsko, 694 m) (Fig. 8).

The area covered by the Ralsko Geopark is poorly inhabited, and in fact, most of the area was completely off-limits to visitors for more than half a century. The settlement density in this predominantly forested area was never very high, and in the 1930s, parts of the region began to be used as military training grounds. This land use continued during the World War II and afterwards, including the period of 1968-1991, when most of the area was occupied by the Soviet army (Poštolka 1998). In addition, exploitation of strategic uranium ores occurred in the northern part of the area (Kafka 1998). After the political turnover of $1989 / 1990$ and the withdrawal of Soviet troops, the future of the area was a matter of debate. Research indicated considerable value of wetlands and forests within the former army grounds (Honců 1998), and a decision was made to build future development upon sustainable and nature-based tourism, as well as on general recreation. Despite intentional destruction of many villages during military exercises, high-value cultural objects are located in the outer parts of the area, including impressive ruins of medieval castles of Ralsko, Bezdĕz, and Děvin. There are also interesting examples of mining heritage (Kühn 2005).
In 2013, work began towards the establishment of a national geopark in the former military area and its surroundings. This status was granted in 2016, by a decree of the Ministry of Environment of Czech Republic (Kubaliková 2018). The southern part of the Ralsko Geopark is included within the Kokořínsko-Máchův kraj Protected Landscape Area.

\section{Other Localities}

In addition to sites and areas contained within the three geoparks, there are several important localities in their close vicinity, highly relevant to the main theme explored in this paper (Figs. 1, 3, and 7). We decided to include them into the analysis, realizing that geopark boundaries are all but administrative lines, not necessarily respecting natural conditions. Moreover, future developments may change geopark boundaries, and these relevant localities may be included. Finally, visitors taking part in geotourism and geoeducational activities are unlikely to limit their engagement to geopark areas if interesting localities also exist nearby. Thus, these additional sites are the following:

- localities in the Zittauer Gebirge in Germany, which include outcrops of thermally altered sandstone (die Orgel), rock clefts lined with iron precipitates (Zigeunerstuben, Grosse Felsengasse), and quarries of hardened sandstone (Mühlsteinbrüche);

- Dutý kámen nature monument in Czechia, with outstanding evidence of columnar jointing in sandstone;

- Čertova zed' national nature monument in Czechia remnants of basaltic dykes, largely destroyed by quarrying; 

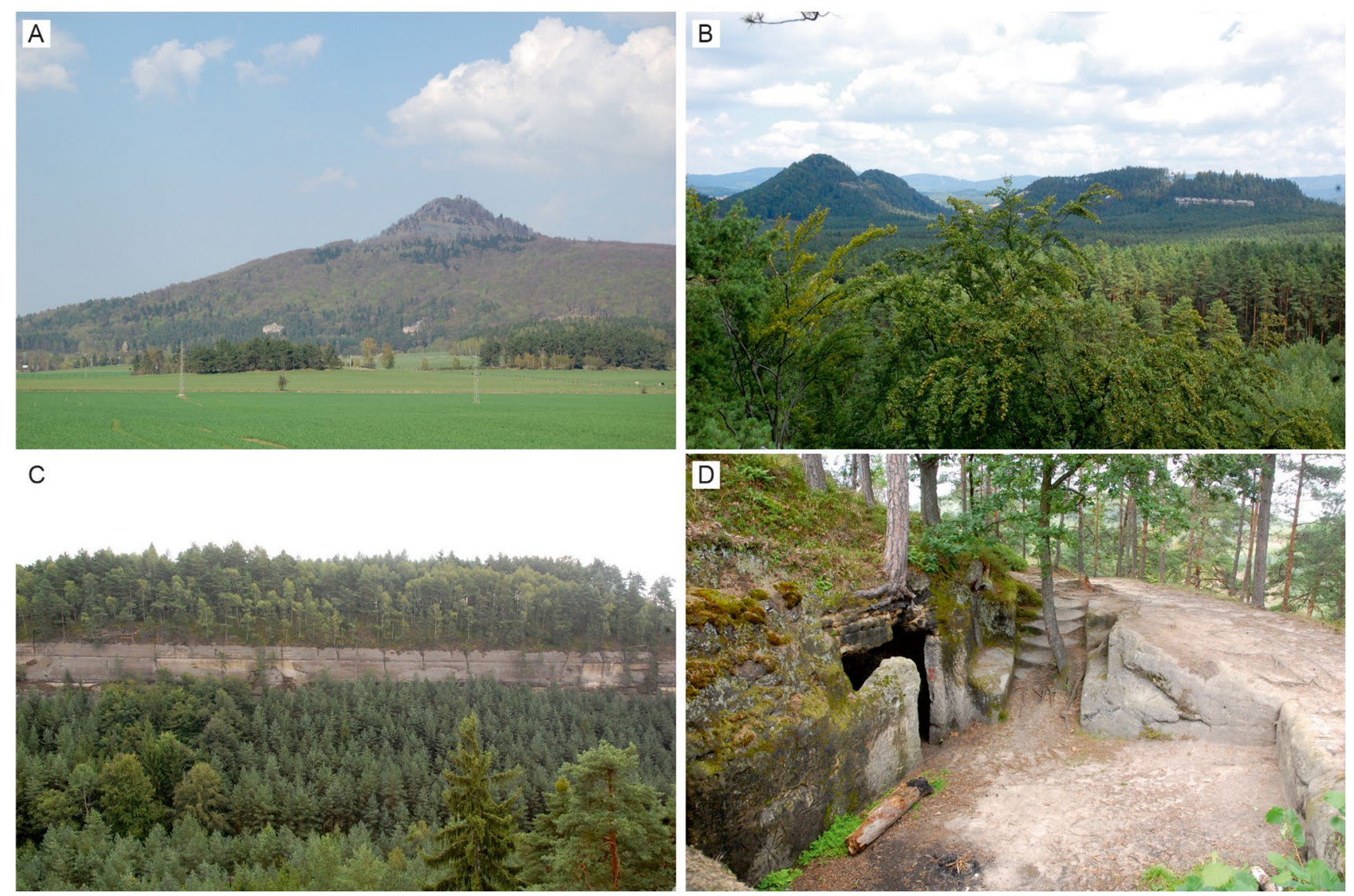

Fig. 8 Geoheritage of the Ralsko Geopark. A Volcanic neck of Mt. Ralsko; B different morphological types of sandstone hills: conical and tabular; C long sandstone cliffs at Dlouhý kámen; D remnants of a hill-top medieval fortress, with younger hermitage rooms cut into sandstone rock

- Baba hill in Czechia, where volcanic rocks emplaced as a sill build a gentle terrain swell amidst a plain cut across mudstones;

- Łupki nature monument in Poland - an outstanding example of sandstone xenoliths in basalt.

\section{Volcanic and Sedimentary - How Are They Related?}

\section{Geology}

The most widespread sedimentary rocks in all three geoparks are sandstones and mudstones (siltstones) of Late Cretaceous age, deposited within an interval from Cenomanian to Coniacian/Santonian, over some 15 million years (Skoček and Valečka 1983; Milewicz 1997). Coarser and finer variants, with variable content of quartz, alternate in the vertical profile, reflecting changing palaeogeographic conditions of the epicontinental sea (Milewicz 1997; Uličný et al. 2009; Leszczyński and Nemec 2019; Nádaskay et al. 2019). Various localities (geosites - existing or potential) offer insights into the sedimentary architecture of Cretaceous deposits and help to unravel the complex history of sedimentation and erosion (Adamovič et al. 2006, 2010; Migoń and PijetMigoń 2021). Post-depositional deformation of Cretaceous strata was limited in extent, largely confined to the immediate vicinity of major reverse faults such as the Lusatian Fault (Coubal et al. 2014, 2015) or the Jerzmanice Fault (Solecki 2011), active at the Cretaceous/Palaeogene transition. As a consequence, Cretaceous beds are increasingly tilted towards the fault, re-oriented to vertical, or even overturned. The best examples of this deformation are provided by two vertical (hogback) ridges of Suché skály (Fig. 4D) and Vranovský hřeben in the Bohemian Paradise UGG, whereas the cuesta of Klokočí skály shows less intense and more distant effects of fault activity (Mertlik and Adamovič 2016). Otherwise, both Cretaceous and older sedimentary rocks lie nearly horizontally.

Subsequent brittle deformations of the crust, involving also the near-surface sedimentary packages, resulted in the origin (or reactivation) of numerous deep-seated faults, used by magma to ascend towards the contemporaneous Earth surface. In some cases, fault zones were filled by long, but 
narrow (a few metres at most) subvolcanic dykes (Skála et al. 2015). The most famous example of such phenomenon is the 20 km long, SW-NE trending Čertova zed' (Devil's Wall) to the east of Ralsko Geopark, which is a part of a larger dyke swarm. Its composition is basaltic, but it is included in the polzenite-group lamprophyres, widespread in this part of the Bohemian Cretaceous Basin. However, in contrast to basalts, polzenites proved weakly resistant to weathering and alteration, with some geomorphological consequences. Fault zones and their intersections were also used for the ascent of voluminous magma batches, which fed volcanoes or solidified at shallow depths in the form of laccolithic bodies. In numerous places, one can notice distinct alignments of several separate volcanic bodies, suggesting an existence of a deep-seated discontinuity. Volcanism occurred intermittently throughout the Cenozoic and not simultaneously in the three areas considered here. Polzenite dykes are Late Cretaceous in age, some of the volcanic rocks in the Ralsko National Geopark have Late Eocene-Late Oligocene ages, basalts in the Land of Extinct Volcanoes and the southeastern part of the Bohemian Paradise UGG are mainly of Early to Middle Miocene age (Badura et al. 2005; Birkenmajer et al. 2007; Rapprich et al. 2007; Ulrych et al. 2011), whereas basalt flows at Mt. Kozákov are only 5 Ma old (Cajz et al. 2009). The majority of volcanoes were probably monogenetic scoria cones, although of different sizes. They were subsequently eroded to different levels, so that today some volcanic localities show abundant pyroclastic deposits (Rapprich et al. 2007), whereas others are formed entirely by lava that solidified within volcanic vents (Birkenmajer 1967) or within craters (Rapprich et al. 2007). The latter often display impressive patterns of columnar jointing, promoted as natural curiosities in the past and increasingly as geotourist destinations at present. Larger volcanic structures also existed, as inferred from the large size of residual landforms (e.g., Mt. Ralsko - Fig. 8A), and remnants of lava flows disassociated from the source areas have also locally survived.

Magmatism imparted various effects on the host sedimentary rocks (Adamovič et al. 2010). Thermal effects included hardening of sandstones and mudstones, which turned into a silica-rich rock called porcellanite. At the contact, heating of sandstone by hot magmatic fluids and its subsequent cooling led to the origin of columnar jointing in sandstones, analogous to that in the lava itself. This phenomenon may have affected both the sandstone mass along the line of lava ascent (e.g., Dutý kámen, die Orgel) and sandstone xenoliths within the lava (e.g., Łupki, Diablak). Among indirect effects, the most widespread and most impressive are secondary iron precipitations from hot hydrothermal fluids circulating through the rock in the late stages of magmatic activity. They take a multitude of forms, such as subvertical planar bodies along basalt/sandstone contact (linings) and joints, undulating crusts, tubular bodies, subhorizontal bodies along bedding planes, spheroids, and dispersed iron within sandstone, resulting in reddish colour of an otherwise pale yellow-coloured rock (Adamovič 2002, 2016; Vařilová 2007).

\section{Landform Evolution on Complex Bedrock}

Geomorphological evolution of sedimentary tablelands overlooked by volcanic hills and pierced by magmatic dykes occurred within bedrock that was non-uniform in terms of rock strength and rock resistance against weathering and erosion. Most solid volcanic rocks, despite different composition, proved much stronger than the adjacent sedimentary rocks, as testified by the results of Schmidt hammer strength tests (Placek 2007). Therefore, although the lifetimes of scoria cones may be short and they may become quickly denuded, the pace of further surface lowering upon an exposed lava plug (conduit) was much slower and the former volcanic edifices may have actually increased in height over time. This long-term differential denudation produced impressive rock-controlled landforms such as the regular cone of Mt. Ostrzyca or Mt. Wilkołak in the Land of Extinct Volcanoes (Wocke 1927; Birkenmajer 1967; Migoń and Pijet-Migoń 2016), the monumental dome of Mt. Ralsko in the Ralsko Geopark (Janoška 2013), and twin towers of Trosky in the Bohemian Paradise UGG (Petronis et al. 2015). Partially preserved scoria cones around the town of Jičin are not so grand in terms of scenery, but offer valuable insights into the history of post-eruptive landform evolution and help to constrain the amount of surface lowering (Rapprich et al. 2007). The emergence of hard volcanic rocks from their sedimentary surroundings in the Pleistocene had further geomorphic consequences. Exposed to severe climatic conditions, jointed basalts were breaking down into smaller fragments due to mechanical, mainly frost weathering. In this way, periglacial block fields developed on steep slopes of volcanic necks (e.g., Mt. Ostrzyca, Mt. Ralsko) and have become a valuable component of regional geoheritage (Migoń and Pijet-Migoń 2016).

The effects of volcanism-related differential weathering can be also observed on a smaller scale, within sandstone outcrops. They are related to the phenomenon of iron precipitation. Iron crusts are much harder than the adjacent sandstone and weather much more slowly. Depending on the original pattern of iron impregnations, these iron-rich parts protrude sharply from the host rock for several centimetres, such as at Divadlo nature monument in the Ralsko Geopark, or form a continuous siding along a joint surface, as in the Prachovské skály rock city in the Bohemian Paradise UGG or at Děvín hill in the Ralsko Geopark (Mertlík et al. 2002, Mikuláš and Adamovič 2002, Mertlík and Adamovič 2016). Beyond geoparks, excellent examples of 
iron precipitation can be inspected in the Zittauer Gebirge (Zigeunerstuben, Grosse Felsengasse).

\section{Other Themes}

Relationships between volcanic activity and volcanic products versus host sedimentary rocks are not limited to rock record and landform evolution, but they also underpin some aspects of the human use of mineral resources and cultural heritage, and are important for biodiversity.

The ascent and circulation of magmatic and hydrothermal fluids within the sedimentary rocks led to the release of substantial amount of iron, present both in some volcanic dykes, especially in polzenites, and in sandstones. The concentration of iron, although small in absolute values, was found sufficient to justify economic exploitation of these poor limonitic ores (Kühn et al. 2001). Iron mining and smelting developed in the area of Ralsko Geopark, especially in its northern part, where iron-bearing polzenite dykes are abundant. The tangible heritage of mining includes minor, usually infilled and overgrown pits, spoil heaps, collapsed shafts, and, as a main attraction, deep open clefts cutting through sandstone hills, left after the dyke was partly excavated. The most impressive example is located at Schächtenstein in the Ralsko Geopark, where excavation produced a narrow $(<2 \mathrm{~m})$ trench nearly $70 \mathrm{~m}$ long and $17 \mathrm{~m}$ deep at maximum (Kühn et al. 2001).

Hardening of sandstone next to volcanic bodies, otherwise rather friable, long supported local millstone industry. The largest quarries are located in the Zittauer Gebirge, near the town of Jonsdorf (Mühlsteinbrüche = millstone quarries), and are impressive artificial pits surrounded by vertical walls up to $50 \mathrm{~m}$ high (Gerth 2012). The history of millstone quarrying that finally terminated in 1918 goes back to the sixteenth century. In Bohemia, the most famous locality is Milštejn in the Lužické Mts., in the proximity of the Ralsko Geopark. Both basalt and sandstone were also quarried as building stones, mainly for local use, and numerous old buildings were constructed from these local rocks.

Landscape contrast between volcanic hills and much more subdued sedimentary terrain is reflected in various land uses. The role of volcanic elevations, overlooking the surrounding tableland, was always special, and they were used for two main purposes: military/defensive and religious. Each area provides examples of medieval castles strategically located on top of a hill (Trosky, Veliš in the Bohemian Paradise UGG; Grodziec in the Land of Extinct Volcanoes; Ralsko in the Ralsko Geopark), some converted later into monasteries (Bezděz). In the eighteenth to nineteenth centuries, some smaller edifices became local pilgrimage centres, with chapels erected in an exposed position on the hilltop (Vyskeř, Zebín, Sv. Anna in the Bohemian Paradise UGG). By contrast, the surrounding flatlands on sedimentary rocks were mainly used for agricultural purposes, although some were left under forest if sandy soils were found unsuitable to support agriculture and there was better farmland available nearby. For example, most of the terrain within the Ralsko Geopark was continuously forested and forest exploitation was among the main occupations and the main source of income for the local population (Pecháčková 1998). Dense erosional dissection, as in the eastern part of the Ralsko Geopark, further prevented settlement and economic development.

Co-existence of volcanic and sedimentary rocks is also reflected in vegetation patterns, which show adjustment to both soil and landform diversity. Soils developed upon basalt and phonolite tend to be rather alkaline and stony in texture (leptosols, regosols), whereas those on sandstones and siliceous mudstones are predominantly acid, poor in nutrients, and sandy (podzols, cambisols). Consequently, sedimentary flatlands are less diverse biologically, with widespread stands of planted coniferous trees, mainly pine and spruce, or they have long been used as arable lands and pastures. By contrast, volcanic elevations and steep-sided sandstone hills remained as local islands of biodiversity, with old beech stands, lime and maple communities on basaltic scree slopes, and thermophilous oak forests. In the Land of Extinct Volcanoes, the latter were shown to belong to the most species-rich forest communities in Poland (Reczyńska 2015; Reczyńska and Świerkosz 2018). Craggy basaltic slopes are also valuable habitats for thermophilous rocky grasslands and shrubs, which also colonize abandoned basalt quarries in the early stage of vegetation succession (Reczyńska and Świerkosz 2018). Considerable botanical value of volcanic hills finds its confirmation in establishing numerous protected areas. In the Bohemian Paradise UGG and its surroundings, they include, among others, the nature reserve of Příhrazské skály and nature monuments of Trosky, Zebín, and Dubolka. In the Ralsko Geopark, protected areas include the nature reserve of Ralsko and the nature monument of Jelení vrchy, both on volcanic rocks, and Děvín and Ostrý on sandstone hardened in the proximity of a polzenite dyke, with scree forest communities and old beech stands. In the Land of Extinct Volcanoes, the most valuable is the nature reserve on the isolated cone of Mt. Ostrzyca, with very high biodiversity on a regional scale.

\section{Opportunities for Geoeducation and Interpretation - Discussion}

\section{Existing Interpretation Provisions and Challenges}

In line with the concept of geoparks (Zouros 2008; Zouros and Valiakos 2010; Brilha 2018), education and interpretation are among the key activities aimed at both tourists 
and local inhabitants, especially young generation. Various means of interpretation are possible, depending on the target group and technical constraints (Migon 2018), with some themes explored more often than others. Moreover, narratives may vary, ranging from very simple and condensed information to more elaborate storytelling, which can be increasingly helped by modern technologies (Cayla and Martin 2018; Pica et al. 2018). Geoparks considered in this paper follow this wide spectrum of interpretation strategies, although - as a general observation - causal relationships between volcanism and the host sedimentary rocks are rather seldom explored. This may be related to the common belief that geological history and landform evolution are themes difficult to absorb by the majority of visitors (see Drápela et al. 2021), whereas the expected simplification does not allow one to develop complicated stories easily, using limited number of words (e.g., on panels) (Doucek and Zelenka 2018), unless these stories are told in person during a guided tour.

Among the most popular means available to everyone at any time are educational trails, with information panels (boards) erected at specific localities. Collectively, these panels should tell the story or, at least, provide basic encyclopedia-like information. Trails may be focused on one particular theme or explore various themes, including geology, landscape, living world, and cultural heritage. Technological advances make now possible to design trails, which are not waymarked in the field and equipped with panels, but exist in the virtual space. Two trails set up in the Ralsko Geopark provide relevant examples, both addressing the subject of volcanism and its impact on the host rocks. The trail 'Following iron mining heritage' (our translation) in the northern part of the geopark has several stops at former mine workings and outcrops of thermally altered sandstones (Fig. 9A), but most stops do not have real information panels, whereas leaflets available for downloading from the geopark website contain rather limited information. By contrast, the trail 'Across the Bukové hills' in the southern part does have panels at most of the stops, and geology and geomorphology are not the only themes presented. Of particular interest is information about co-existence of different types of rock and relationships between land cover, vegetation patterns, and geology. The trail at Baba hill provides information about geology, old quarrying, plants, and animals, and is more customer-oriented, in that panels are double-sided, addressed to adults and children, respectively.

In addition to trails, interpretation panels can be erected at singular locations, commenting about features of particular interest (Fig. 9B, D). Examples from the three geoparks and their surroundings vary in the depth of coverage, from rather
Fig. 9. Examples of interpretation panels. A Introductory panel to the "Following iron mining heritage" trail in the Ralsko Geopark; B panel explaining how magmatic intrusions alter the host sandstone (Zittauer Gebirge); $\mathbf{C}$ explanation of origin and various effects of iron precipitation in sandstones - a stop at "Across the Bukové hills" trail in the Ralsko Geopark; D one of four panels explaining geology of Čertova zed' magmatic dyke, containing information for an advanced visitor; $\mathbf{E}$ panel on Mt. Velká Buková ("Across the Bukové hills" trail) in the Ralsko Geopark shows snapshots from the evolution of the landscape and explains the panoramic view
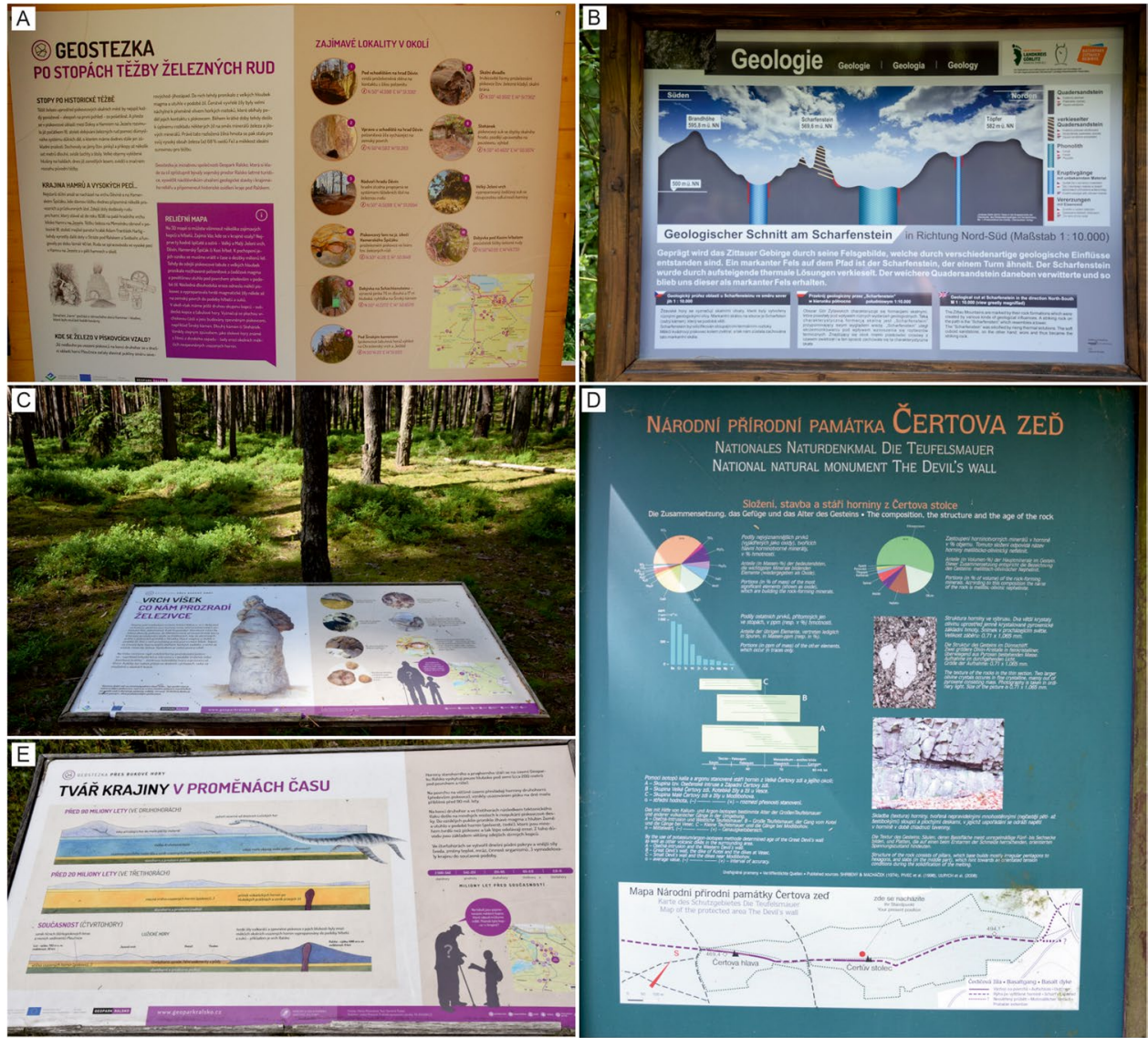
advanced interpretation at Čertova zed', which requires some a priori interest and understanding of geosciences (Fig. 9D), to very simple and not always very informative panels elsewhere. Landscape dimension of volcanism is presented by a series of small plaques at Mt. Vyskeř, pointing towards other volcanic elevations in the vicinity. Several other viewpoint localities may play a similar role, with some equipped with interpretation panels (e.g., at Velká Buková in the Ralsko Geopark; Fig. 9E), although more common are simple sketches or reproduced photos, where annotations are limited to the names of individual peaks. Interestingly, in each area, there exist localities, which are excellent geosites if considered in terms of accessibility and clarity of outcrop or view, but lack any interpretation provisions (as of June 2021). These unexplained sites include the symbol of the Bohemian Paradise UGG, the Trosky hill, the Děvín hill in the Ralsko Geopark, and Mt. Wilkołak in the Land of Extinct Volcanoes. In the former case, this deficit of onsite information is partly offset by the availability of webaccessible animations presenting the origin of the twin neck (https://www.youtube.com/watch?v=jvWAw_riOe4; access date 2021-06-22, see Rapprich et al. 2017), although nothing at Trosky itself informs about this educational website, run by the Czech Geological Survey.

Given the complexity of the issue, more opportunities may be provided by guided tours and educational workshops. Tours are occasionally offered by the Ralsko Geopark, and many of these are clearly focused on volcanic and sandstone landforms, as well as iron mining. In the other two geoparks, educational activities are mainly conducted off-site, in purposefully built educational centres, but it is not clear from the existing advertisements how (or if) the implications of volcanic activity on sandstones and sandstone landscapes are shown. Unfortunately, guided tours cannot be a regular offer in understaffed geoparks and, in particular, outside the geoparks.

One of the main challenges in holistic geointerpretation resides in the fact that 'classic' geosites (e.g., singular geological outcrops or landforms) do not always allow one to tell or grasp the whole story. This is because of the scale involved, too small and local to show the complexity of geological history and landscape evolution, including its controlling factors. Therefore, complementary to specific geosites are viewing points (Migoń and Pijet-Migoń 2017b), allowing for broader landscape interpretation, and annotated terrain models, which may broaden the perspective even further (Migoń and Różycka 2021). Consequently, a tiered approach to interpret volcanic-sedimentary linkages is suggested here, split into three spatial scales, related to landscape, landforms, and outcrops.

\section{Opportunities for Interpretation at Landscape Level}

At the landscape level, the relationships between volcanic versus sedimentary rocks are best examined from panoramic viewpoints (viewpoint geosites sensu (Migoń and Pijet-Migon 2017b)). A common sight is the coexistence of extensive tracts of planar or gently rolling relief and sharply emerging hills, usually conical or dome-like (Fig. 10). These terrain elevations, mostly built of hard volcanic rock, are
Fig. 10 Two panoramic views to show solitary hills of volcanic or subvolcanic origin, rising above sedimentary flatlands. A Land of Extinct Volcanoes Geopark, a view from the viewing tower at Mt. Zawodna; B Ralsko Geopark, a view from Mt. Velká Buková
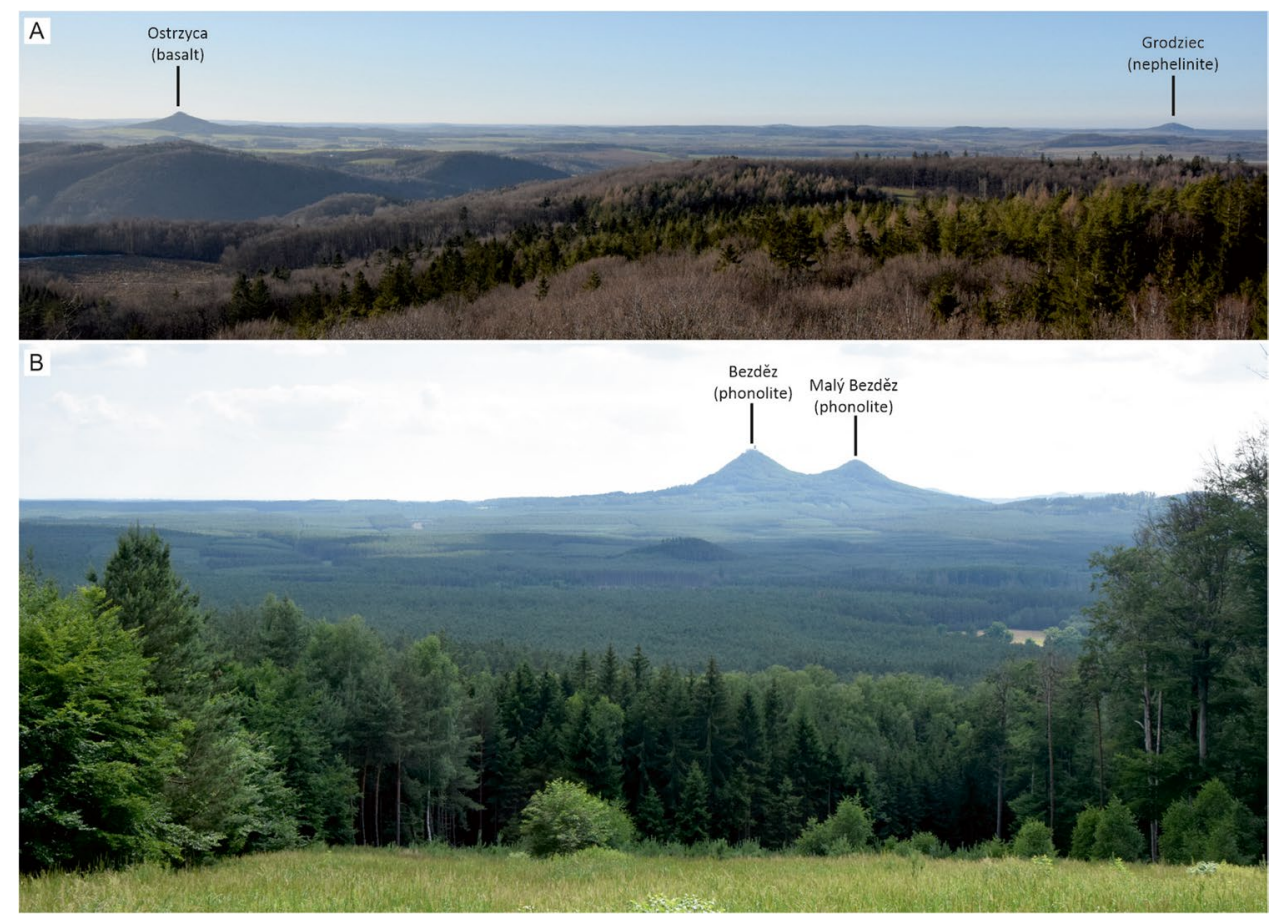
exposed laccoliths, volcanic conduits (necks) or former lava lakes filling the craters, indicating the location of subvolcanic intrusions or ancient volcanoes. Former scoria cones are less striking due to higher erodibility of poorly consolidated volcanic materials, but they may also form distinctive landmarks. Hills of volcanic origin may occur in isolation, or in clusters, although spatial clustering does not necessarily mean volcanic activity at the same time (Rapprich et al. 2007). The intervening flatlands are typically underlain by sedimentary rocks, although isolated mesas and buttes, capped by hard sandstone beds, may also occur.

However, in humid climates as in Central Europe, where vegetation hides soils and rocks, panoramic viewpoints will not play the intended role if no explanation is provided. In contrast to arid areas, where the volcanic/sedimentary contact is typically reflected in rock/soil colour (see Ruban et al. 2021), in vegetated terrains, the landscape alone may not give clues to the geology and hill shapes may be deceptive. For example, Fig. 11 might suggest that the view includes volcanic hills both in the middle ground and in the far distance. In reality, none of the three hills in the middle ground owes its existence to the presence of resistant volcanic rocks, although some interesting linkages with magmatic activity can be demonstrated. The tabular hill to the left is a sandstone-capped mesa, whereas the two hills to the right are both built of hardened sandstone, altered in the proximity of a polzenite dyke that runs through these elevations. Thus, they illustrate a very complex geomorphic role of magmatic dykes. The hills in the far distance, in turn, are proper volcanic necks.

All three geoparks considered here have several excellent vantage points, which may be used for the purpose of interpreting large-scale landscapes. Some are located on the summits of volcanic hills themselves, whereas others occupy different places in the landscape. The former include Mt. Ostrzyca (Land of Extinct Volcanoes), Mt. Mužský (Bohemian Paradise UGG), and Mt. Ralsko (Ralsko Geopark). Given that volcanic hills typically have considerable heights, the views are particularly extensive. Examples of viewpoints belonging to the second group are Krásná výhlidka on Mt. Kavčí kopec (Ralsko Geopark) (Fig. 11) or the viewing tower at Mt. Zawodna (Land of Extinct Volcanoes) (Fig. 10A). However, panoramic viewpoints are seldom explained as geotourist sites. Even if information boards are present, information is limited to simple silhouette naming, without mentioning geology behind the scenery (e.g., at Krásná výhlidka or Mt. Grodziec). Ideal provisions should include annotated cross-sections or 3D models, with simplified geology draped over topography.

In addition to singular panoramic viewpoints, a potentially interesting experience can be provided by 'volcanic routes' designed for car users and, particularly, cyclists. Cycling is promoted as a means to practice sustainable, 'green' tourism, and allows one to reach places inaccessible for motorists and to stop at places unsuitable for car parking, increasing appreciation of specific landscapes due to longer time spent awheel. Its relevance to geotourism is increasingly argued for (Hose 2018; Lugeri and Farabollini 2018). Cycling routes around several ancient volcanic edifices, along an itinerary that might include a few spots with landscape interpretation provisions, are options to explore in geoparks and beyond.

\section{Opportunities for Interpretation at Landform Level}

In the areas presented in this study, most of the volcanic hills seen from the panoramic viewpoints are accessible using hiking trails or can be freely explored even if they are

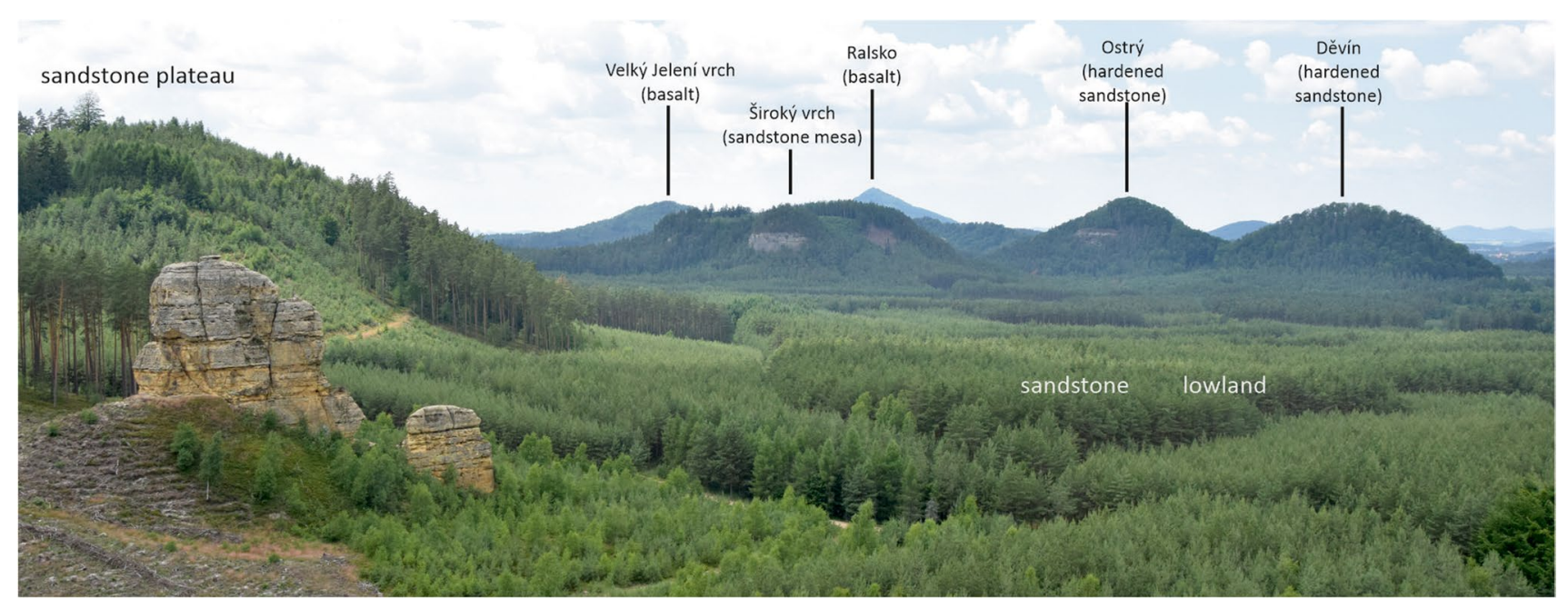

Fig. 11 Panoramic annotated view from the Krásná výhlidka viewing point (Ralsko Geopark) 
beyond the trail network and signposting is missing. Those off-limits are due to ongoing quarry operations (e.g., Mt. Wilkołak in the Land of Extinct Volcanoes). None of the hills is completely under strict nature protection, rendering them totally inaccessible, although formal restrictions within the nature reserve at Mt. Ostrzyca preclude exploration of the most interesting hillslope sections. Trails to the volcanic summits allow the visitors to examine how general morphology changes following the transition from sedimentary bedrock at the footslope to volcanic bedrock in the upper slope and to see smaller landforms associated with volcanic rocks. For example, at Mt. Ostrzyca, the path becomes ever steeper while going up and the following interpretative stops can be developed along the trail from the nearby village of Proboszczów: (1) a view of the steep-sided basaltic neck rising from a gently sloping sedimentary terrain, (2) shallow excavations in Permian sedimentary rocks at the footslope, (3) basaltic scree extending over sedimentary rocks, (4) periglacial block fields in basalt, (5) mid-slope crags, and (6) the summit crag and the panoramic viewpoint (Fig. 12). Geoscientific explanation can be complemented by simultaneous presentation of how plant communities replace one another in relation to change in geology and topography.

A similar concept can be implemented at Mt. Ralsko, where the sedimentary sandstone bedrock at the footslope is exposed in the form of picturesque cliffs and rock towers (Vranovské skály). After negotiating rather inconspicuous middle slopes, extensive basaltic block fields and rock cliffs up to $20 \mathrm{~m}$ high illustrate typical hilltop morphology associated with volcanic necks. Here too the corresponding vegetation pattern change can be commented. Mt Zebín in the Bohemian Paradise UGG is a steep-sided, $70 \mathrm{~m}$ high scoria cone, with a small disused quarry in the lower slope that shows the feeding basaltic dyke. Rising from a flat surface underlain by Cretaceous mudstones and offering panoramic views of the Jičín Volcanic Field from the top, with outcrops of both lava and scoria, it is an ideal place to be developed as a geotourist destination. The current educational trail to the top addresses various themes, with volcanic history as but one of them, so that there is room to enhance interpretation.

The most impressive example of a rock-controlled landform that owes its origin to variable rock strength is the twin basaltic neck of Trosky in the Bohemian Paradise UGG (Fig. 4C; Janoška 2013; Rapprich et al. 2017). This is a site of multiple values, both natural - as a geosite, as well as cultural, due to the presence of ruins of a medieval castle. The tower is an excellent viewing point, although other volcanic hills in the geopark are not seen well due to considerable distance. In contrast to other volcanic hills, the eye-catching necks of Trosky rise abruptly from the adjacent terrain, essentially without intermediate, moderately inclined slopes. Columnar jointing of basalt can be locally observed within the castle ruins.

\section{Opportunities for Interpretation at Outcrop Level}

At the local scale, various interactions between pre-existing rocks and volcanic activity can be shown and examined in natural and in man-made outcrops (quarries, road cuts). Selected localities include the following:

- Děvín-Ostrý (Hamerský Špičák)-Schächtenstein (Ralsko Geopark) - these three hills, well visible from the viewpoint at Krásná výhlidka (Fig. 11), are built of hard-
Fig. 12 Scenes from a proposed educational trail to Mt. Ostrzyca in the Land of Extinct Volcanoes Geopark. A A view from the footslope; $\mathbf{B}$ trail to the top, with basaltic scree overlying sedimentary bedrock; C extensive bare scree slopes near the summit; D panoramic view from the summit, with the silhouette of the basaltic neck of Mt. Wilkołak in the skyline
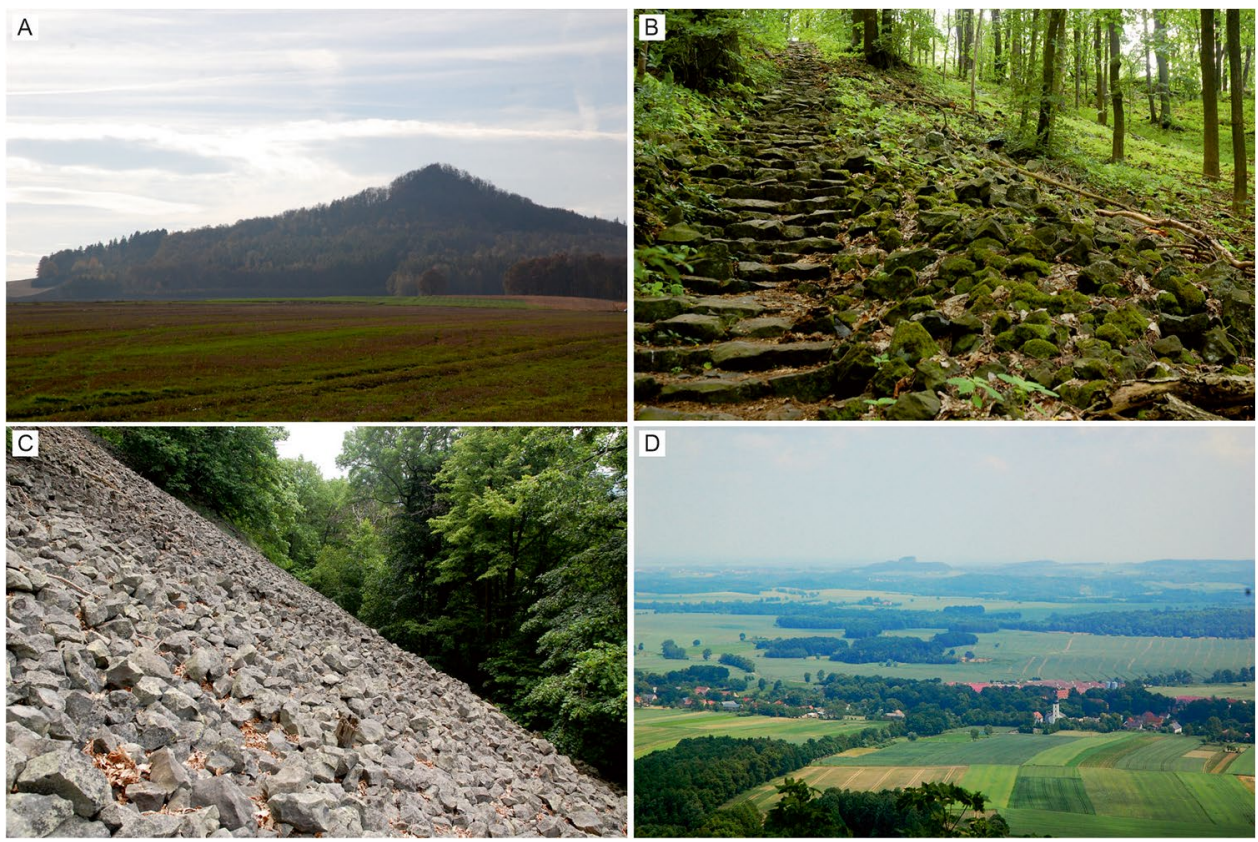
ened sandstone intruded by a polzenite dyke (Fig. 13). The dyke, which is just a few metres wide, crosses the hills in their axial parts, but is of low resistance, having been altered in the hydrothermal stage of its emplacement. In addition, it is iron-rich and was probably mined in several periods throughout the history. The legacy of mining includes shafts and galleries, as well as surface excavations in the form of deep and narrow clefts, such as at Schächtenstein (Kühn et al. 2001; Kühn 2005). In the area of castle ruins on Mt Děvín, one can see the contact of soft polzenite and hard sandstone, but on-site interpretation facilities are missing, despite inclusion of the locality into the trail 'Following iron mining heritage'.

- Divadlo (Ralsko Geopark) - this is one of the best examples of iron impregnations of sandstone, with diverse shapes and patterns (Mikuláš 1997; Mikuláš and Adamovič 2002), fairly easily accessible. Among them, the most eye-catching are the so-called 'iron pipes' or 'iron logs', seen in cross-section as a few centimetres thick ribbons of very hard ironstone (Fig. 14A). Their contorted geometry shows the pathways of hydrothermal fluids through the host rock. Divadlo is also located on the trail 'Following iron mining heritage' and an interpretation panel was erected next to sandstone crags.

- Káčov (Bohemian Paradise UGG) - in a small old quarry within a basalt plug, one can see cooling joints in the volcanic rock and altered mudstones, turned into porcellanite (Fig. 14B) (Janoška 2013). The site is a nature monument, but on-site explanation is very limited.
- Dubolka hill (Bohemian Paradise UGG) - this low elevation cut by an abandoned quarry offers a good insight into the structure of a simple scoria cone (Janoška 2013). In the main pit, the walls built of pyroclastic materials are more than $20 \mathrm{~m}$ high (Fig. 14C), whereas xenolithrich layers of volcanic ash and breccia can be seen at the entrance. However, the site is not at all developed and dense vegetation makes it almost inaccessible during the plant growth season.

- Čertova zed' (Czechia) - the name was given to a nearly 20-km-long basaltic dyke that cuts through the host sandstone (Janoška 2013; Skála et al. 2015). According to oral tradition, the dyke used to stand out as a rock wall up to $10 \mathrm{~m}$ high over most of its length, but many sections were completely quarried away as a valuable stone resource. It was proclaimed a protected locality (national nature monument) in 1964, although quarrying was terminated earlier. The most impressive remaining section, known as the Devil's Chair (Fig. 14D), is easily accessible by a marked trail, and two information panels, aimed at visitors with some a priori knowledge of volcanic geology (Fig. 9D), were erected on the spot.

- Dutý kámen (Czechia) - this is a classic locality of columnar thermal jointing in sandstone and, at the same time, an illustration of sandstone hardening along the contact with polzenite (Adamovič et al. 2010). The dyke itself is mostly altered, soft, and not visible, whereas the sandstone supports a short $(600 \mathrm{~m})$ ridge that includes rock towers and bastions. The site owes its fame to fan-like arrangement of thin columns, best
Fig. 13 Geoheritage and mining heritage at Děvín hill. A A close-up view of the contact between polzenite dyke (left) and host sandstone (right), with an entrance to the old mining gallery; B iron lining of the contact surface between polzenite and sandstone; $\mathbf{C}$ entrance to a cross adit below the castle walls
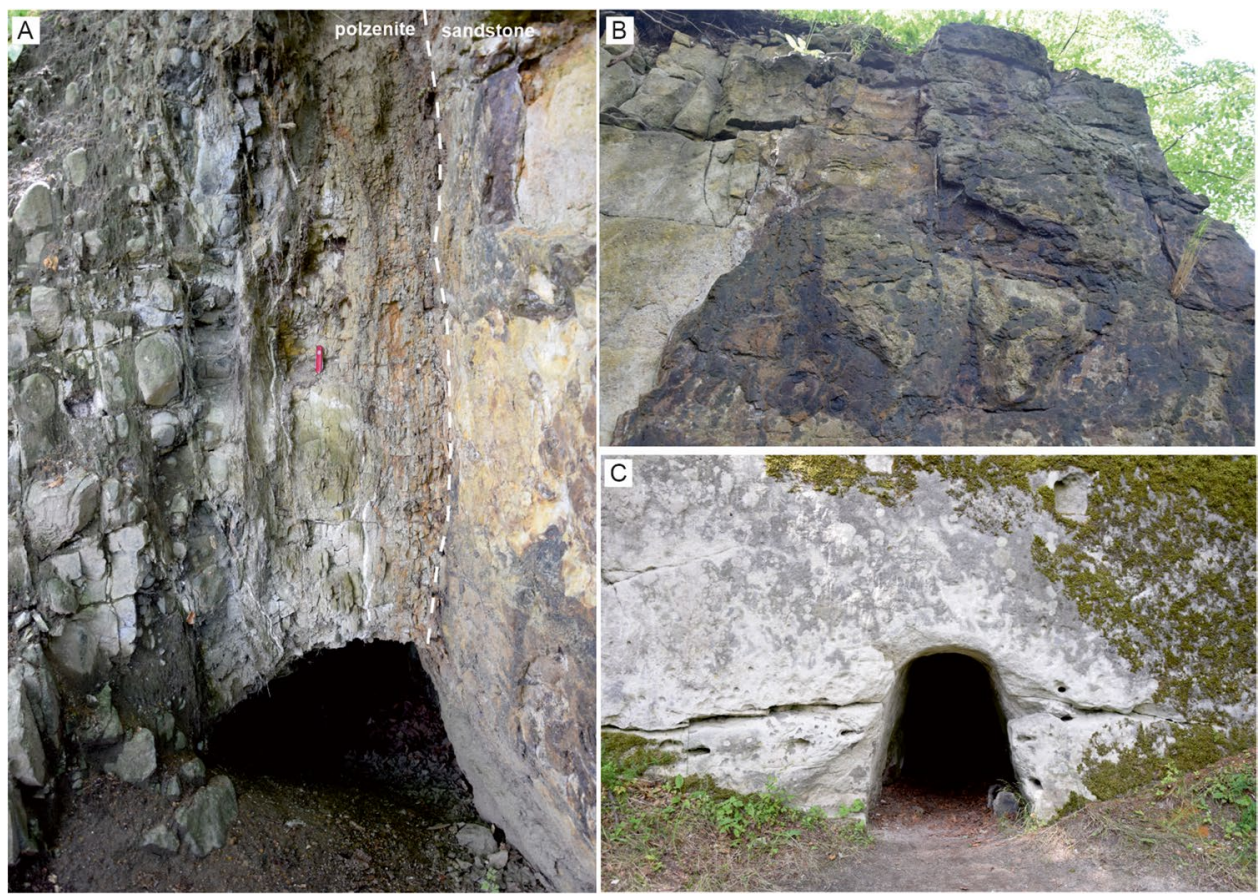
Fig. 14 Examples of geosites from the study areas, illustrating various relationships between volcanism and sedimentary rocks. A Tubular iron incrustations (Divadlo nature monument, Ralsko Geopark); B contact between basalt (right) and thermally altered mudstones (left) (Káčov hill, Bohemian Paradise UGG); C pyroclastic deposits in an old quarry (Dubolka hill, Bohemian Paradise UGG); D remnant of the Čertova zed' dyke, forming a rock wall developed in basalt; $\mathbf{E}$ thermal columnar jointing in sandstone (Dutý kámen nature monument, N Czechia); $\mathbf{F}$ small-scale columnar jointing in a sandstone xenolith, approximately $2 \mathrm{~m}$ wide (Łupki nature monument, SW Poland); $\mathbf{G}$ abandoned millstone quarry at Jonsdorf (Zittauer Gebirge, Germany); $\mathbf{H}$ small-scale columnar jointing in sandstone (die Orgel, Zittauer Gebirge, Germany)
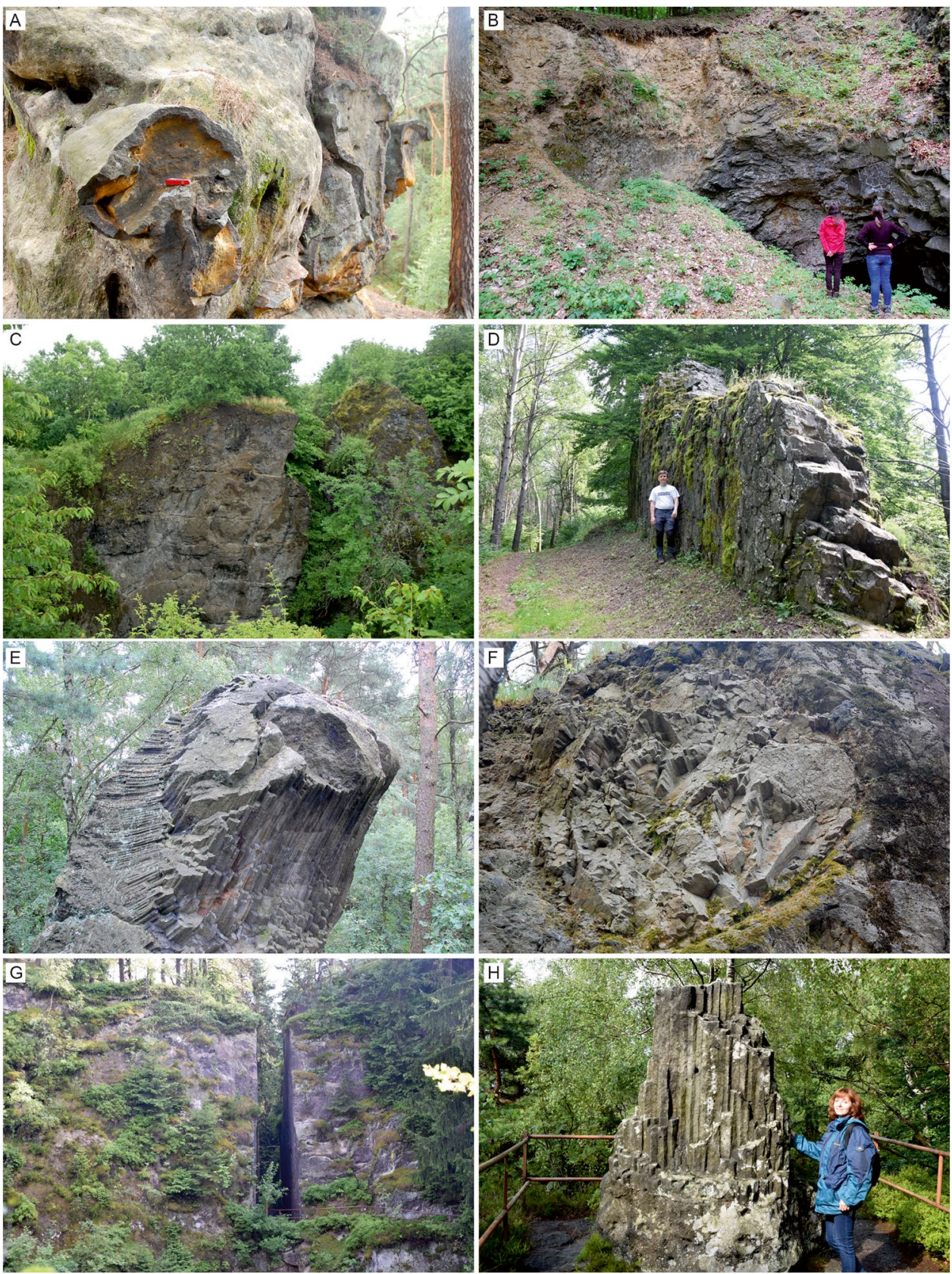

seen on the Vějiŕ (Fan) outcrop (Fig. 14E). It is also a site with numerous rock bas-reliefs and a viewing point on the tip of the ridge, accessible via rock-hewn steps. Geological explanation is, however, surprisingly limited.

- Lupki (Poland) - an old quarry exposes large sandstone xenoliths in basalt, some as much as $2 \mathrm{~m}$ long, with well-developed columnar jointing seen in cross-section (Fig. 14F). In addition, many small-size xenoliths occur within basaltic breccia. The basalt itself shows perfect columnar jointing (Wagner 1961). The site is at roadside location and is protected as a nature monument
- Mühlsteinbrüche (Germany) - this is a cluster of old quarries above the town of Jonsdorf, where thermally altered sandstone was found ideal for the production of millstones (Gerth 2012). Some quarries are overgrown and hardly accessible, whereas others can be visited. An open-air museum was established in the largest and deepest quarry - the Schwarzes Loch (Fig. 14G). A marked trail connects the quarrying area with the Orgel rock outcrop, representing induced columnar jointing in sandstone (Fig. 14H). Other sites nearby show impressive ironstone linings of deep clefts in sandstone, originated through complete erosion of weaker magmatic dykes 
(Zigeunerstuben and Felsengasse at the sandstone rock group of Nonnenfelsen) (Havránek 2002). Some on-site information on simple boards is provided, but no indepth exploration of the subject is available for a casual visitor.

\section{Conclusions}

Modern conceptual approach to geointerpretation and geoeducation emphasizes the holistic understanding of the environment and urges to highlight linkages between various abiotic, biotic and cultural components. A common feature of three geoparks located in Central Europe, in Czechia and Poland (Bohemian Paradise UNESCO Global Geopark, Land of Extinct Volcanoes Aspiring UNESCO Geopark, Ralsko National Geopark), is the co-existence of Cenozoic volcanic and subvolcanic rocks with thick sedimentary packages of Permian and Mesozoic age, among which sandstones are abundant. However, it is more than a co-existence. Magmatic processes produced various effects in the host sedimentary rocks, some very appealing visually, whereas contrasting resistance of volcanic versus sedimentary rocks to weathering and erosion resulted in the development of attractive varied relief, with impressive conical hills built of resistant basalts and other volcanic rocks. Further causal linkages include the origin of mineral resources, which supported mining activity, enhancement of biological diversity, and specific land use contrasts related to relief and soils. All these circumstances create ample opportunities to develop interpretation and geoeducation focused on these relationships. They can be examined at various, but complementary spatial scales, from the landscape scale to an individual geosite. Thus, different aspects of the general story of how different types of rocks influence each other and how they underpin human activities can be explored at each scale. Geosites are very important localities and illustrate important details, but viewing points provide the necessary wider context, whereas thematic trails are best suited to explore the landform scale. In any case, interpretation provisions and site management are important, if the viewpoints, the landforms, and the outcrops are to be meaningful to an interested visitor. Geoparks and localities presented in this paper offer many examples of good practice, but there is room for further improvements and, surprisingly, several iconic sites lack any explanation or information.

Acknowledgements We are grateful to Mr. Kacper Jancewicz for assistance in the preparation of some figures. Perceptive comments from journal reviewers, including one particularly meticulous review, helped us to improve the paper and correct its deficiencies.

\section{Declarations}

Competing Interests The authors declare no competing interests.

Open Access This article is licensed under a Creative Commons Attribution 4.0 International License, which permits use, sharing, adaptation, distribution and reproduction in any medium or format, as long as you give appropriate credit to the original author(s) and the source, provide a link to the Creative Commons licence, and indicate if changes were made. The images or other third party material in this article are included in the article's Creative Commons licence, unless indicated otherwise in a credit line to the material. If material is not included in the article's Creative Commons licence and your intended use is not permitted by statutory regulation or exceeds the permitted use, you will need to obtain permission directly from the copyright holder. To view a copy of this licence, visit http://creativecommons.org/licenses/by/4.0/.

\section{References}

Abratis M, Viereck L, Büchner J, Tietz O (2015) Route to the volcanoes in Germany. Conceptual model for a geotourism project interconnecting geosites of Cenozoic volcanism. Z Dt Gesell Geowiss 2:161-185. https://doi.org/10.1127/zdgg/2015/0035

Adam A (2004) Rzeźba strukturalna Pogórza Kaczawskiego i północno-wschodniej części Pogórza Izerskiego. Przyr. Sudetów 4:175-190

Adamovič J (2002) Occurrences of Fe-oxyhydroxides in sandstones of the Bohemian Cretaceous Basin. In: Adamovič J, Cílek V (eds) Ironstones. Pseudokarst reports 2. Knih České speleo spol $37: 7-40$

Adamovič J (2016) The Kokořín area: Sandstone landforms controlled by hydrothermal ferruginization. In: Pánek T, Hradecký J (eds) Landscapes and Landforms of the Czech Republic. Springer, Switzerland, pp 153-164

Adamovič J, Mikuláš R, Cílek V (2006) Sandstone districts of the Bohemian Paradise: emergence of a romantic landscape. Geolines 21:1-100

Adamovič J, Mikuláš R, Cílek V (2010) Atlas pískovcových skalních měst České a Slovenské Republiky: Geologie a geomorfologie. Academia, Praha, p 460

Badura J, Pécskay Z, Koszowska E, Wolska A, Zuchiewicz W, Przybylski B (2005) New age and petrological constraints on Lower Silesian basaltoids, SW Poland. Acta Geodyn Geomater 2 3(139):7-15

Becerra-Ramírez R, Gosálvez RU, Escobar E, González E, SerranoPatón M (2020) Guevara D (2020) Characterization and geotourist resources of the Campo de Calatrava Volcanic Region (Ciudad Real, Castilla-La Mancha, Spain) to develop a UNESCO Global Geopark Project. Geosciences 10:441. https://doi.org/10.3390/ geosciences10110441

Birkenmajer K (1967) Bazalty dolnośląskie jako zabytki przyrody nieożywionej (Engl. summ. Lower Silesian basalts as monuments of inanimate nature). Ochr Przyr 32:225-276

Birkenmajer K, Pécskay Z, Grabowski J, Lorenc MW, Zagożdżon P (2007) Radiometric dating of the Tertiary volcanics in Lower Silesia, Poland. V. K-Ar and palaeomagnetic data from Late Oligocene to Early Miocene basaltic rocks of the North-Sudetic Depression. Ann Soc Geol Pol 77:1-16

Brilha J (2018) Geoheritage and Geoparks. In: Reynard E, Brilha J (eds) Geoheritage. Assessment, protection and management. Elsevier, Amsterdam, pp 323-335 
Cajz V, Rapprich V, Schnabl P, Pécskay Z (2009) Návrh litostratigrafie neovulkanitů východočeské oblasti (Engl. summ. A proposal on lithostratigraphy of Cenozoic volcanic rocks in Eastern Bohemia). Geosci Res Reports for 2008, 9-14, Praha.

Cayla N, Martin S (2018) Digital geovisualization technologies applied to geoheritage management. In: Reynard E, Brilha J (eds) Geoheritage. Assessment, protection and management. Elsevier, Amsterdam, pp 289-303

Coubal M, Adamovič J, Málek J, Prouza V (2014) Architecture of thrust faults with alongstrike variations in fault-plane dip: anatomy of the Lusatian Fault, Bohemian Massif. J Geosci 59:183-208

Coubal M, Málek J, Adamovič J, Štěpančíková P (2015) Late Cretaceous and Cenozoic dynamics of the Bohemian Massif inferred from the paleostress history of the Lusatian Fault belt. J Geodyn 87:26-49. https://doi.org/10.1016/j.jog.2015.02.006

Dóniz-Páez J, Beltrán-Yanes E, Becerra-Ramírez R, Pérez NM, Hernández PA, Hernández W (2020) Diversity of volcanic geoheritage in the Canary Islands, Spain. Geosciences 10:390. https:// doi.org/10.3390/geosciences 10100390

Doucek J, Zelenka J (2018) New trends in geoproducts development: Železné Hory National Geopark case study. Czech J Tourism 7(2):179-195. https://doi.org/10.1515/cjot-2018-0010

Dowling RK (2013) Global geotourism - an emerging form of sustainable tourism. Czech J Tourism 2(2):59-79. https://doi.org/10. 2478/cjot-2013-0004

Dowling RK, Newsome D (2018) Geotourism: definition, characteristics and international perspectives. In: Dowling RK, Newsome D (eds) Handbook of Geotourism. Edward Elgar, Cheltenham, pp 1-22

Drápela E, Boháč A, Böhm H, Zágoršek K (2021) Motivation and preferences of visitors in the Bohemian Paradise UNESCO Global Geopark. Geosciences 11:116. https://doi.org/10.3390/geoscience s11030116

Erfurt-Cooper P (2010) Active geothermal and volcanic environments as tourist destinations. In: Dowling R, Newsome D (eds) Global Geotourism Perspectives. Goodfellow Publishers, Oxford, pp 33-38

Erfurt-Cooper P (ed) (2014) Volcanic tourist destinations. Springer, Berlin-Heidelberg 384pp

Gerth A (2012) Reise in die Erdgeschichte der Oberlausitz, des Elbsandsteingebirges und Nordböhmens. Oberlausitzer Verlag, Spitzkunnersdorf $1024 \mathrm{pp}$

Gordon J (2018a) Geoheritage, geotourism and the cultural landscape: Enhancing the visitor experience and promoting geoconservation. Geosci 8:136. https://doi.org/10.3390/geosciences8040136

Gordon J (2018b) Geotourism and cultural heritage. In: Dowling RK, Newsome D (eds) Handbook of Geotourism. Edward Elgar, Cheltenham, pp 61-75

Gray M (2011) Other nature: geodiversity and geosystem services. Environ Conserv 38:271-274. https://doi.org/10.1017/S0376 892911000117

Harangi S (2014) Volcanic heritage of the Carpathian-Pannonian region in Eastern-Central Europe. In: Erfurt-Cooper P (ed) Volcanic tourist destinations. Springer, Berlin-Heidelberg, pp 103-124

Havránek P (2002) Lužické hory. In Adamovič J, Cílek V (eds) Železivce České křídové pánve. Knih České speleo spol 38: 56-72

Henriques MH, dos Reis RP (2021) Storytelling the geoheritage of Viana do Castelo (NW Portugal). Geoheritage 13:46. https://doi. org/10.1007/s12371-021-00569-5

Honců M (1998) Biological and landscape values of the former Ralsko military training area. Geogr Sbor ČGS 103:300-319

Hose TA (2008) Towards a history of geotourism: definitions, antecedents and the future. In: Burek CV, Prosser CD (eds) The History of Geoconservation. Geological Society, London, pp 37-60
Hose TA (2010) The significance of aesthetic landscape appreciation to modern geotourism provision. In: Newsome D, Dowling RK (eds) Geotourism: the tourism of geology and landscapes. Goodfellow, Oxford, pp 13-25

Hose TA (2018) Awheel Along Europe's rivers: geoarchaeological trails for cycling geotourists. Open Geosci 10:413-440. https:// doi.org/10.1515/geo-2018-0033

Janoška M (2013) Sopky a sopečné vrchy České republiky. Praha, Czech Republic, Academia, p 416

Kafka T (1998) Uranium industry and Ralsko. Geografie - Sbor Čes geogr spol 103:382-389

Kubaliková L (2016) Promoting geomorphological heritage: bringing geomorphology to people. In: Pánek T, Hradecký J (eds) Landscapes and landforms of the Czech Republic. Springer, Switzerland, pp 387-410

Kubaliková L (2018) Czech Republic: the planning and management of geotourism's hidden resourses. In: Dowling RK, Newsome D (eds) Handbook of geotourism. Edward Elgar, Cheltenham, pp 417-432

Kühn P, Havránek P, Adamovič J (2001) Geologische Aspekte des Eisenerz-Bergbaus in den Sandsteinen der Lausitzer Kreide Geol Saxonica 46-47: 125-137

Kühn P (2005) Die Toneisensteine des Lausitzer/Zittauer Gebirges und ihre Entstehung. Ber Naturforsch Ges Oberlausitz 13:35-48

Leszczyński S, Nemec W (2019) Sedimentation in a synclinal shallowmarine embayment: Coniacian of the North Sudetic Synclinorium, SW Poland. Depositional Rec 6:144-171. https://doi.org/10.1002/ dep2.92

Lima EA, Machado M, Guerreiro M, Nunes JC, Costa MP (2018) Geological heritage management in small islands: the example of the Azores UNESCO Global Geopark (Portugal). Geoheritage 10:659-671. https://doi.org/10.1007/s12371-018-0328-6

Lugeri FR, Farabollini P (2018) Discovering the landscape by cycling: a geo-touristic experience through Italian badlands. Geosciences 8:291. https://doi.org/10.3390/geosciences 8080291

Megerle HE (2020) Geoheritage and geotourism in regions with extinct volcanism in Germany; case study southwest Germany with UNESCO Global Geopark Swabian Alb. Geosciences 10:445. https:// doi.org/10.3390/geosciences 10110445

Mertlik J, Adamovič J (2016) Bohemian Paradise: sandstone landscape in the foreland of a major fault. In: Pánek T, Hradecký J (eds) Landscapes and Landforms of the Czech Republic. Springer, Switzerland, pp 195-208

Mertlík J, Adamovič J, Nešporová M (2002) Český ráj. In: Adamovič J, Cílek V (eds) Železivce České křídové pánve. Knih České speleo spol 38: 105-127

Migoń P (2018) Geo-interpretation - how and for whom? In: Dowling RK, Newsome D (eds) Handbook of Geotourism. Edward Elgar, Cheltenham, pp 223-233

Migoń P, Pijet-Migoń E (2016) Overlooked geomorphological component of volcanic geoheritage - diversity and perspectives for tourism industry, Pogórze Kaczawskie region, SW Poland. Geoheritage 8:333-350. https://doi.org/10.1007/s12371-015-0166-8

Migoń P, Pijet-Migoń E (2017a) Interpreting geoheritage at New Zealand's geothermal tourist sites-systematic explanation versus storytelling. Geoheritage 9:83-95. https://doi.org/10.1007/ s12371-016-0185-0

Migoń P, Pijet-Migoń E (2017b) Viewpoint geosites - values, conservation and management issues. Proc Geol Assoc 128:511-522. https://doi.org/10.1016/j.pgeola.2017.05.007

Migoń P, Pijet-Migoń E (2020) Late Palaeozoic volcanism in Central Europe - geoheritage significance and use in geotourism. Geoheritage 12:43. https://doi.org/10.1007/s12371-020-00464-5

Migoń P, Pijet-Migoń E (2021) Not simply volcanoes - geoheritage of the Cretaceous system in the Land of Extinct Volcanoes Geopark, 
West Sudetes (SW Poland). Geotourism 60-61:3-22. https://doi. org/10.7494/geotour.2020.60-61.3

Migoń P, Różycka M (2021) When individual geosites matter lesschallenges to communicate landscape evolution of a complex morphostructure (Orlické-Bystrzyckie Mountains Block, Czechia/ Poland, Central Europe). Geosciences 11:100. https://doi.org/10. 3390/geosciences 11020100

Mikuláš R (1997) "Železné klády” - výjimečné skalní útvary v křídových pískovcích Ralské pahorkatiny. Ochr Přir 52:117-118

Mikuláš R, Adamovič J (2002) Okolí Hamru a Svébořic. In: Adamovič J, Cílek V (eds) Železivce České křrídové pánve. Knih České speleo spol 38: 47-55

Milewicz J (1997) Górna kreda depresji północnosudeckiej (lito- i biostratygrafia, paleogeografia, tektonika oraz uwagi o surowcach). Acta Univ Wratisl, Prace Geol-Miner 61:1-58

Nádaskay R, Žák J, Sláma J, Sidorinová T, Valečka J (2019) Deciphering the Late Paleozoic to Mesozoic tectono sedimentary evolution of the northern Bohemian Massif from detrital zircon geochronology and heavy mineral provenance. Int J Earth Sci 108:2653-2681

Németh K, Gravis I, Németh B (2021) Dilemma of geoconservation of monogenetic volcanic sites under fast urbanization and infrastructure developments with special relevance to the Auckland Volcanic Field, New Zealand. Sustainability 13:6549. https://doi. org/10.3390/su13126549

Newsome D, Dowling RK (2005) The scope and nature of geotourism. In: Dowling RK, Newsome D (eds) Geotourism. ButterworthHeinemann, Oxford, pp 3-25

Ólafsdóttir R, Dowling R (2014) Geotourism and geoparks-a tool for geoconservation and rural development in vulnerable environments: a case study from Iceland. Geoheritage 6:71-87. https:// doi.org/10.1007/s12371-013-0095-3

Ólafsdóttir R, Tverijonaite E (2018) Geotourism: a systematic literature review. Geosciences 8:234. https://doi.org/10.3390/geosc iences 8070234

Pásková M, Zelenka J (2018) Sustainability management of UNESCO global geoparks. Sust Geosci Geotour 2:44-64. https://doi.org/10. 18052/www.scipress.com/SGG.2.44

Pásková M, Zelenka J, Ogasawara T, Zavala B, Astete I (2021) The ABC Concept - Value added to the Earth heritage interpretation? Geoheritage 13:38. https://doi.org/10.1007/s12371-021-00558-8

Pecháčková I (1998) Settlement and population. Geografie - Sbor Čes geogr spol 103:367-381

Petronis MS, Brister AR, Rapprich V, van Wyk de Vries B, Lindline J, Mišurec J (2015) Emplacement history of the Trosky basanitic volcano (Czech Republic): paleomagnetic, rock magnetic, petrologic, and anisotropy of magnetic susceptibility evidence for lingering growth of a monogenetic volcano. J Geosci 60:129-147. https://doi.org/10.3190/jgeosci.196

Pica A, Reynard E, Grangier L, Kaiser C, Ghiraldi L, Perotti L, Del Monte M (2018) GeoGuides, urban geotourism offer powered by mobile application technology. Geoheritage 10:311-326. https:// doi.org/10.1007/s12371-017-0237-0

Pijet-Migoń E, Migoń P (2019) Promoting and interpreting geoheritage at the local level-bottom-up approach in the Land of Extinct Volcanoes, Sudetes, SW Poland. Geoheritage 11:1227-1236. https:// doi.org/10.1007/s12371-019-00357-2

Placek A (2007) Basaltic hills as structural landforms-morphometry versus rock strength (a study from the Kaczawskie upland, SW Poland). Univ Ostravensis Acta Fac Rer Nat 237, Geogr - Geol 10:111-127

Poštolka V (1998) Conversion and reuse of the former military training area of Ralsko. Geografie - Sbor Čes geogr spol 103:285-299

Rapprich V, Cajz V, Košták M, Pécskay Z, Řídkošil T, Raška P, Radoň M (2007) Reconstruction of eroded monogenic Strombolian cones of Miocene age: a case study on character of volcanic activity of the Jičín Volcanic Field (NE Bohemia) and subsequent erosional rates estimation. J Geosci 52:169-180. https://doi.org/10.3190/ jgeosci.011

Rapprich V, Lisec M, Fiferna P, Závada P (2017) Application of modern technologies in popularization of the Czech volcanic geoheritage. Geoheritage 9:413-420. https://doi.org/10.1007/ s12371-016-0208-x

Reczyńska K (2015) Diversity and ecology of oak forests in SW Poland (Sudetes Mts.). Phytocoenologia 45:85-105

Reczyńska K, Świerkosz K (2018) Volcanic heritage of Góry and Pogórze Kaczawskie. In: 27th Congress of the European Vegetation Survey, 23-26 May 2018, Wrocław, Poland, pp 1-20

Ren F, Simonson L, Pan Z (2013) Interpretation of geoheritage for geotourism - a comparison of Chinese geoparks and national parks in the United States. Czech J Tourism 2(2):105-125

Rogowski M (2016) The potential of the Sudetes Mountains for the development of geotouristic products. Geotourism 46-47:59-80. https://doi.org/10.7494/geotour.2016.46-47.59

Ruban DA, Mikhailenko AV, Yashalova NN (2021) The power of colour in geoheritage studies and marketing: some tentative reflections. Geologos 27:57-65. https://doi.org/10.2478/ logos-2021-0005

Scarlett JP, Riede F (2019) The dark geocultural heritage of volcanoes: combining cultural and geoheritage perspectives for mutual benefit. Geoheritage 11:1705-1721. https://doi.org/10.1007/ s12371-019-00381-2

Šibrava V, Havlíček P (1980) Radiometric age of Plio-Pleistocene volcanic rocks of the Bohemian Massif. Věst Ústř Úst Geol 55:129-139

Skála R, Ulrych J, Ackerman L, Krmíček L, Fediuk F, Balogh K, Hegner E (2015) Upper Cretaceous to Pleistocene melilitic volcanic rocks of the Bohemian Massif: petrology and mineral chemistry. Geol Carpathica 66:197-216. https://doi.org/10.1515/ geoca-2015-0020

Skoček V, Valečka J (1983) Paleogeography of the Late Cretaceous Quadersandstein of central Europe. Palaeogeogr, Palaeoclim, Palaeoecol 44:71-92

Škvor J (1982) Makroreliéf a mezoreliéf Prachovských skal. Acta Univ Carolinae, Geogr 17:61-79

Słomski P, Jankowska J, Rozpędowska E (2019) Land of extinct volcanoes geopark - education for everyone. Geotourism 58-59:1728. https://doi.org/10.7494/geotour.2019.58-59.16

Solecki A (2011) Rozwój strukturalny epiwaryscyjskiej pokrywy platformowej w obszarze synklinorium północnosudeckiego. In: Żelaźniewicz A, Wojewoda J, Ciężkowski W (eds) Mezozoik i kenozoik Dolnego Śląska. WIND, Wrocław, pp 19-36

Szepesi J, Harangi S, Ésik Z, Novák TJ, Lukács R, Soós I (2017) Volcanic geoheritage and geotourism perspectives in Hungary: a case of an UNESCO World Heritage Site, Tokaj Wine Region Historic Cultural Landscape, Hungary. Geoheritage 9:329-349. https://doi. org/10.1007/s12371-016-0205-0

Uličný D (2001) Depositional systems and sequence stratigraphy of coarse-grained deltas in a shallow-marine, strike-slip setting: the Bohemian Cretaceous Basin, Czech Republic. Sedimentology 48:599-628. https://doi.org/10.1046/j.1365-3091.2001.00381.x

Uličný D, Laurin J, Čech S (2009) Controls on clastic sequence geometries in a shallow-marine, transtensional basin: the Bohemian Cretaceous Basin, Czech Republic. Sedimentology 56:1077-1114. https://doi.org/10.1111/j.1365-3091.2008.01021.x

Ulrych J, Dostal J, Adamovič J, Jelínek E, Špaček P, Hegner E, Balogh K (2011) Recurrent Cenozoic volcanic activity in the Bohemian Massif (Czech Republic). Lithos 123:133-144. https://doi.org/10. 1016/j.lithos.2010.12.008

Valečka J (1979) Paleogeography and lithofacies development in the northwestern part of the Bohemian Cretaceous Basin. Sbor Geol Věd, Geol 33:47-81 
Vařilová Z (2007) Occurrences of Fe-mineralization in sandstones of the Bohemian Switzerland National Park (Czech Republic). In: Härtel H, Cílek V, Herben T, Jackson A, Williams R (eds) Sandstone Landscapes. Academia, Prague, pp 25-33

Vítek J (1980) Pseudokrasové tvary v Prachovských skalách. Čs Kras $31: 45-56$

Wagner S (1961) Kolumnowa oddzielność porwaków piaskowca w bazalcie z okolicy Wlenia. Kwart Geol 5:217-220

Wocke MF (1927) Der Basalt in der Schlesischen Landschaft. Veröffent Schles Gesell Erdk 5:1-51

Zangmo Tefogum G, Dongmo Kagou A, Guilomalire ND, Gountie Dedzo M, Kamgang P (2016) The volcanic geoheritage of the Mount Bamenda calderas (Cameroon Line): assessment for geotouristic and geoeducational purposes. Geoheritage 9:255-278. https://doi.org/10.1007/s12371-016-0177-0

Zouros NC (2008) European Geoparks Network: transnational collaborations on Earth heritage protection, geotourism and local development. Geotourism 1(12):3-22
Zouros N, Valiakos I (2010) Geoparks management and assessment. Bull Geol Soc Greece 43:965-977. https://doi.org/10.12681/bgsg. 11262

\section{Website resources}

Geopark Kraina Wygasłych Wulkanów (n.d.) Available online: https:// www.gorykaczawskie.pl/ (accessed on 13 July 2021)

Geopark Ralsko (n.d.) Available online: https://www.visitralsko.com/ (accessed on 13 July 2021)

Globální geopark UNESCO (n.d.) Bohemian Paradise. Available online: http://www.geoparkceskyraj.cz/ (accessed on 13 July 2021) 